|Araştırma Makalesi / Research Article|

\title{
YDS ve YÖKDiL Sınavlarının Yabancı Dil Eğitimi Üzerine Etkileri
}

\section{Washback Effects of YDS and YOKDIL on Foreign Language Teaching}

\section{Murat Polat ${ }^{1}$}

Anahtar Kelimeler
sınav etkisi
yabancı dil eğitimi
yabancı dil yeterlik
YDS
YÖKDiL

\section{Keywords}

washback effect

language education

language proficiency

YDS

YOKDIL

Başvuru Tarihi/Received

25 Mart 2020

Kabul Tarihi /Accepted

01.09.2020
Öz

Türkiye'de yabancı dil seviyesini tespit etme ve yabancı dil yeterliğini ölçme amacıyla uygulanan YDS (Yabancı Dil Bilgisi Seviye Tespit Sınavı) ve YÖKDiL (Yükseköğretim Kurumları Yabancı Dil Sınavı) çoktan seçmeli sınavlar olduğundan ve dinleme, konuşma, yazma gibi becerileri ölçmediğinden adayların yabancı dil öğrenme ve öğrendikleri dili kullanma algı ve alışkanlıklarına doğrudan veya dolaylı yoldan etki edebilmektedirler. Çoktan seçmeli sınavlar kullanılarak yapılan yabancı dil beceri ölçümlerinin adayların yabancı dil öğrenme algı ve yöntemlerini ne yönde etkilediğinin araştırılması, Türkiye'de sıklıkla altı çizilen dil öğrenme sorunsalının çözümlenmesine katkıda bulunabilir; zira Türkiye'de yabancı dilde yeterli düzeyde iletişim kuramama ve o dili istenilen seviyede konuşamama gibi sıkıntıların nedenlerinden biri de ÖSYM tarafından öteden beri kullanılan ve değiştirmeye pek yanaşılmayan yabancı dil ölçme yöntemleri olabilir. Bu varsayımdan hareketle bu araştırmada YDS ve YÖKDiL sınavlarına giren akademisyenlerin çoktan seçmeli dil sınavları ve bu sınavların yabancı dil eğitimine etkileriyle ilgili görüşleri alınmış ve bu görüşler ısıı̆ı̆ında Türkiye'de yabancı dil ölçme konusunda benimsenen yöntemlerin dil eğitimi üzerindeki etkileriyle ilgili saptamalar yapılmıştır. Nitel yöntem benimsenerek yapılan bu araştırmada Eskişehir ilindeki 3 devlet üniversitesinde çalışan toplam 43 akademisyenin bu sınavların adayların dil öğrenme yöntemleri, dil derslerinin konu ve içerikleri, kullandıkları materyaller ve öğrenme çıktıları üzerindeki etkilerini bulmayı amaçlayan veriler yarı-yapılandırıımış yüz yüze görüşme tekniğiyle toplanmıs, kodlanmış ve analiz edilmiștir. Çalışma sonucunda ortaya çıkan sonuçlar çoğu katııımcının YDS ve YÖKDiL sınavlarının yabancı dil eğitim yöntemleri, materyalleri, dil eğitim ortamları ve öğrenme çıktıları üzerine olumsuz etki ettiğini düşündüğünü ve bu sınavlarda başarılı olmalarına rağmen okuma becerileri hariç konuşma, yazma ve dinleme gibi diğer dil becerilerinden memnun olmadıklarını göstermiştir.

\section{Abstract}

YDS (Foreign Language Proficiency Exam) and YOKDIL (Higher Education Foreign Language Test) which are administered to measure candidates' foreign language levels and language proficiency in Turkey may affect test-takers' language learning methods, habits and their attitudes directly or indirectly since neither of these tests measure speaking, writing or listening skills in the target language. To be able to find alternative solutions for the foreign language education problem in Turkey, studies, which address the issue how those multiple-choice formatted tests affect test-takers' language learning attitudes and methods, could be useful since the assessment methods which have been used so far by OSYM in Turkey with regards to foreign language proficiency could be one of the reasons why people can't speak or communicate in the target language well. Considering the above hypothesis, this study aims both to collect the views of academics, who took YDS or YOKDIL before, on multiple choice language tests, analyse those views in terms of test washback effect and make some conclusions related to the effects of such tests on test-takers' language learning styles. In this qualitative study, 43 academicians working in 3 state universities in Eskisehir, Turkey were interviewed face to face to be able to investigate the possible effects of YDS and YOKDIL, on their language learning methods, materials, contexts and learning outcomes. Their views were collected, coded and encrypted for analysis. The results revealed that YDS and YÖKDiL have negative washback effects on language leaning methods, materials, language learning contexts and outcomes in Turkey. Although they have passed those tests, participants were mostly dissatisfied with their current English speaking, listening, writing skills. As for the reading skills, most of the academicians reported positive effects of the language exams.

${ }^{1}$ Anadolu Üniversitesi, Yabancı Diller Yüksekokulu, Eskişehir, TÜRKiYE, https://orcid.org/0000-0001-5851-2322

Alıntı/Citation: Polat, M. (2020). YDS ve YÖKDiL Sınavlarının Yabancı Dil Eğitimi Üzerine Etkileri. Kastamonu Education Journal, 18(3), 2188-2202. doi: 
Extended Abstract (Only for Turkish Articles)

\section{Introduction}

The phenomenon defined as test washback effect is the direct or indirect impact of exams on any kind of formal education and training (Ching, 2009; Hawkey, 2006; Külekçi, 2016; McEwen, 1995; Özmen, 2011; Stobart, 2003). Washback effect can be classified as positive or negative washback depending on the effect it makes on learning. In some cases, exams have positive impacts on students' learning since they encourage them study more. However, there are also cases that achievement or competency tests demotivate learners and could be possible sources of stress and anxiety considering their level of difficulty or the mismatch between their questions and the content of the related education. Therefore, it should be interpreted that washback effect of language tests may have both positive or negative impacts on language teaching methods, materials, learning outcomes and even student motivation. Studies on washback effects of high-stakes tests on language learners' motivation and their desire in language learning in Turkey revealed that such tests have mostly negative impacts on language learning. A number of studies including Külekçi (2016), Yavuzer \& Göver (2012), and Akın (2016) on washback effects of Turkish high-stakes language tests called as YDS and YOKDIL revealed that such language proficiency tests have a positive effect on learners' reading habits in the target language since they have various parts on assessing reading skills. On the other hand, YDS and YOKDiL have negative washback effects on learners' developing their skills in speaking, writing and listening since those exams have no questions targeting these communicative skills. Research on this issue in Turkey has mostly focused on learners' anxiety levels whereas little has been done to investigate these exams' pedagogic impacts on language learning methods, materials, contexts and outcomes. Therefore, this study aimed to examine the washback effects of YDS and YOKDiL on language leaning methods, materials, language learning contexts and outcomes.

\section{Method}

To be able to gain a deeper insight on washback effects of YDS and YOKDiL on language leaning methods, materials, language learning contexts and outcomes, this study was based on qualitative research techniques. It was decided to use case study method among the qualitative research techniques in the study. A number of 43 volunteer academicians from Eskişehir's 3 state universities participated in the study between the years 2018-2019. The participants all took one of the tests including KPDS, UDS, YDS and YOKDIL before. The participants who took KPDS and UDS (language proficiency tests which were used to be done in Turkey before 2013) were also included in the study since those language tests were the same with YDS and YOKDiL considering their multiple-choice questions, item types and test contents. None of the participants were from English Language Teaching department, all took one of the above exams in English and all had the required language proficiency scores. The data of the study were collected through semi-structured inter-views in which a 14-item-question form which was developed by the researcher with the help of 4 academicians (to have expert verification) from related disciplines was used. Before conducting the study, the newly generated question form was also piloted and verified by 3 volunteer academicians from Anadolu University. The interviews were lasted around 20-25 minutes and each interview was recorded and transcribed later by the researcher. A detailed descriptive analysis approach was used to analyse the overall data.

\section{Result and Discussion}

Findings of the study were categorized into four sections concerning the research questions which were aimed to examine the effect of YDS and YOKDIL on language leaning methods, materials, language learning contexts and outcomes in Turkey. As for the washback effect of these exams on language learning methods most participants stated that these multiple-choice language proficiency tests had negative effects on their language learning methods. Most participants complained that because of the exams' content and question types, they had to memorize a great deal of academic vocabulary which they have forgotten in time or have never used properly since they have little or no mastery in speaking and writing in English. Another negative impact of YDS and YOKDIL was observed in participants' spending time not in doing language activities but in practicing test techniques and formulizing some short-cuts in order find the correct item in a multiple-choice test quickly and easily. The academicians regretted that they mostly did the same mistake, in sake of passing the test and taking the required foreign language proficiency grade they didn't care much about learning the target language since their ultimate goal was to pass the language test in the shortest time. Next, considering the effect of the exams on language materials, most of the participants stated that they didn't spend time for learning speaking or writing in English; therefore, the materials they used were consisted of grammar books, multiple choice tests and vocabulary lists while studying English. As for the language learning context of the participants while studying for YDS and YOKDIL, it was understood that language learning/teaching was mostly teacher-centred including the instruction of explicit grammar rules and practicing translation techniques from English to Turkish or vice versa. Finally, in terms of the washback effects of YDS and YOKDIL on their language learning outcomes, participants mostly communicated their disappointment in their English levels. A small number were contented with their English level since they could make translations from research articles and could easily read and understand those articles using the advanced vocabulary knowledge inherited from their past memorizations to pass the exam. However, participants were mostly dissatisfied with their English levels since they had difficulty in speaking and writing in English especially when they joined international events or had to respond some immediate e-mails or phone calls in English. To conclude, this study revealed that YDS and YOKDiL have negative washback effects on language learning methods, materials, language learning contexts and outcomes in Turkey according to the views of academicians who have taken these tests. 
Although they have passed those tests, participants were mostly dissatisfied with their current English speaking, listening and writing skills.

\section{GíRiş}

Ölçme ve değerlendirme süreçlerinde kalite ve başarı için özellikle üzerinde durulan üç önemli kriter vardır: geçerlilik, güvenilirlik ve kullanışlılık (Brown, 1998; Çelik ve Yavuz, 2015; Ertürk, 2015; Heaton, 1988; Messick, 1996; Rashidi ve Javanmardi, 2011). Eğitim süreçlerinin amacına uygun işlemesinin önemi göz önünde bulundurulduğunda, sürecin ne denli sağlıklı işlediğini sınamak için yapılan ölçmenin öncelikle amaca uygun olması ve ne ölçülmesi isteniyorsa onu ölçmesi istenir ve bu ölçme tekrarlandığı zaman benzer sonuçlar vermelidir ki ileride de güvenle uygulanabilsin. Anılan bu özellikleri göz önünde bulundururken de benimsenen metotların kullanışlı ölçme yöntemleri olmaları yani sınavın uygulanmasında asgari görevli, ekipman, kaynak ve zaman gerektirmeleri de ölçme uzmanlarına göre son derece önemlidir (Alderson, 1992, Bachman ve Palmer, 1996; Brown, 1998). Örneğin sınavın geçerliliğini ön planda tutarak bir sınav yaptı̆̆ımızı düşünelim, söz konusu bu test sırf geçerliliği yüksek bir sınav olması kaygısıyla 6-7 saat olamaz, böyle olması planlansa dahi sınava giren adaylar tepki gösterir ve devam etmezler. Bu defa önceliğimiz güvenilirliği yüksek bir sınav olsun; bir test, sonuçlarının güvenilir olduğundan emin olabilmek için yılda 4-5 kez tekrarlanamaz. Bütün bunlar zaman, kaynak ve emek israfı anlamına geleceğinden bu durum sınavları geçerliliği ve güvenirliği yüksek olsalar dahi kullanışlı olmaktan çıkaracaktır. O halde geçerlilik, güvenilirlik ve kullanışlılık ölçmede dengeli bir seviyede olması istenen özelliklerdir ve bunlardan birinin diğerlerinden çok daha baskın olması bu dengeyi bozacak ve diğer ikisinden birinin veya her ikisinin de azalması, geçersiz olması anlamına gelecektir. Örneğin sırf güvenilir sonuçlar veriyor diye ehliyet sınavında güvenilir bir matematik testi uygulamak (evet tekrarı yapıldığında sınav benzer sonuçlar verecektir ve oldukça güvenilir çıkacaktır) adayların ehliyet almak için istenilen beceri ve bilgilerini ölçmeyecektir. Aynı adaylara ölçmenin geçerliliğini artırmak kaygısıyla hem karlı havalarda hem yağmurda hem virajlı yollarda veya test yapılan araca ağır yük yüklüyken ve hatta gece karanlıkta direksiyon sınavı yapmak oldukça geçerli sonuçlar verebilir ama bütün bunları yapmak ne kadar zaman ve imkân gerektirecektir ve dahası bu testler tekrar edildiğinde sonuçların benzer çıkma olasılı̆̆ı ne kadar yüksek olacaktır? Son olarak kullanışlıı̆̆ı ön plana çıkaran bir test düşünün ve bu testte adaylardan sadece sözlü olarak sınavda kullanılan aracı nasıl hareket ettireceği veya acil bir durumda ne yapacağı sorulsun. Bu sorulara adayın cevap vermesi hem kısa zaman alacak hem de oldukça ekonomik bir sınav yapılmış olacaktır, güvenilirliği anlamında da benzer sorular tekrar farklı şekillerde sorulsa belki benzer cevaplar alınacaktır ancak bu tarz bir ölçmede kullanışlıık öne çıkarılırken adayın gerçekten bu söylediklerini yapıp yapamayacağı veya yazıya döktüğü bilgisini alanda uygulama esnasında gösterip gösteremeyeceği bilinmediğinden testin geçerli ölçme yaptığı şüphesi doğacaktır.

Geçerlilik, güvenilirlik ve kullanışııık kriterlerin her birinin istenilen düzeylerde sağlanması bırakınız çok katılımcının aynı anda test edildiği sınavları, küçük çaplı sınavlarda dahi zaman zaman oldukça güçtür ve bu gibi durumlarda bazı öncelikler belirlenir (Cheng, 2005). Türkiye'de merkezi sistemle sınav yapma görev ve sorumluluğu ÖSYM (Öğrenci Seçme ve Yerleştirme Merkezi)'nindir. Ancak, onlarca farklı sınavı hazırlamakla sorumlu ÖSYM özellikle yabancı dil sınavlarının planlanması, içeriğinin hazırlanması, uygulanması ve sonuçlarının değerlendirilmesi konusunda birtakım eleştiriler almaktadır (Akpınar ve Çakıldere, 2013; Karaman, 2015; Külekçi, 2016; Özmen, 2011; Polat, 2018). ÖSYM tarafından Türkiye'de yabancı dil seviye tespit ve yeterliliği ölçümü için kullanılan iki adet sınav vardır: YDS (Yabancı Dil Bilgisi Seviye Tespit Sınavı) ve YÖKDí (Yükseköğretim Kurumları Yabancı Dil Sınavı). Her iki sınavın da amaç, içerik ve ölçme yöntemleri bakımından birbirine benzer sınavlar olduğunu söylemek mümkündür. Her iki sınav da çoktan seçmeli okuma-anlama, çeviri, kelime bilgisi, dilbilgisi, anlamca yakın ifadeyi bulma ve cümle tamamlama gibi sorular içerir ve adaylara çoktan seçmeli sorular üzerinden yabancı dil bilgisi ölçümü yapılarak elde edilen doğru cevaplar hesaplanır ve 100 puan üzerinden puanlama yapılarak adayın yabancı dil seviyesi ve/veya yeterliliği belirlenir.

Adaylar sınav sonuçlarını genellikle iş başvurusunda bulunmak, lisansüstü eğitim almak (yüksek lisans ve doktora programları başvurusu), yabancı dil eğitiminden muaf olmak (Türkiye'de devlet üniversitelerinin büyük bir kısmı üniversite eğitimi öncesi yaklaşık 10 yıl yabancı dil eğitimi almış ve/fakat dil yeterliliğini geçememiş bir kısım öğrencilere yeniden dil eğitimi vermektedir), akademik yükseltme (doçent, profesör unvanı almak), maaş artışı (yabancı dil tazminatı almak) ve öğrenci değişimi veya yurtdışı eğitim programlarına katılmak için kullanmaktadırlar. Bir başka deyişle yabancı dil sınav sonuçları her yaştan ve meslek grubundan adaylar için son derece önemlidir; zira bu sınav sonuçları adayların hayatlarının akışını değiştirebilecek kararların alınması, seçimlerin yapılması ve bir sıralamada öncelik kazanmalarını sağlayabilir. Ancak bu kadar önem arz eden yabancı dil başarısı oranı maalesef Türkiye'de diğer dünya ülkeleri ve Avrupa Birliği Üyeleriyle karşılaştırıldığında oldukça düşüktür. Örneğin, Koru ve Akesson'un (2011) çalışmasında yer alan TEPAV'ın (Türkiye Ekonomi Politikaları Araştırma Vakfı) 2011 senesinde hazırladığı bildiride Türkiye, 44 ülkenin içerisinde olduğu İngilizce Yeterlilik Endeksi konulu bir araştırmada Mısır, Suudi Arabistan, Vietnam, Endonezya gibi eğitim sorunlarıyla boğuşan ülkelerin bile gerisinde kalarak sadece Kazakistan'ın üzerinde sondan ikinci olmuştur. Türkiye'nin yabancı dil eğitimi sorunlarıyla ilgili saptamalar yapılan bu incelemede problemin nedenleri arasında TOEFL ve IELTS

| Kastamonu Eğitim Dergisi, 2020, Vol. 28, No. 5 | 
gibi modern dil testlerinde dil becerileri başlığı altında yer alan iletişim becerileri hususunda Türk adayların yeterince hazırlıklı ve tecrübeli olmadıklarının altı çizilmiştir. Bir diğer araştırmada British Council 2015 senesinde hazırladığı "Türkiye'de Yükseköğretim Kurumlarındaki İngilizce Eğitimi" (British Council Report, 2015) adlı bildiride araştırmacılar tarafından Türkiye'deki yabancı dil eğitimiyle ilgili sorunların bir listesi yapılmış ve bu "yabancı dil öğrenememe sorununun" Türk öğrencilerin üniversite eğitimlerinin kalitesini düşüren ve alan yazındaki kaynaklara ulaşmayı, uluslararası araştırma sonuçlarına erişmeyi ve hem hocaların, hem de farklı ülkelerde eğitim almak isteyen ve bunun için dil yeterliliği dışında diğer tüm şartlara haiz öğrencilerin hareketliliğini kısıtlayan önemli etkenlerden biri olarak görüldüğünün altı çizilmiştir.

Bazı araştırmacılar Türkiye'deki bu yabancı dil eğitimi sorununun yabancı dil ölçme yöntemleriyle de alakalı olabileceğini belirtmiş ve KPDS (Kamu Personeli Yabancı Dil Bilgisi Seviye Tespit Sınavı), ÜDS (Üniversitelerarası Kurul Yabancı Dil Sınavı), YDS ve YÖKDIL gibi sınavların içerikleri ve ölçme anlayışları sebebiyle uzunca bir zamandır adaylar üzerinde yabancı dil öğrenimine ilişkin olumsuz sınav etkileri bıraktıklarını, adayların yabancı dil öğrenmektense o dille ilgili kelime ve kural öğrenmeyi, belirli yapıları ezberlemeyi ve bu şekilde hedef odaklı düşünerek sadece sınavı geçmeyi amaçladıklarını ve bu durumun Türkiye'nin yabancı dil becerilerindeki başarısızlığı düşünüldüğünde hiçte istenmeyen bir tablo yarattığını dile getirmişlerdir (Akın, 2016; Akpınar ve Çakıldere, 2013; Karaman, 2015; Yavuzer ve Göver, 2012; Yeşilyurt, 2016). Bu tablo eğitimciler tarafından da bilindiğinden Türkiye'de çoğu özel üniversiteler ve hatta tercih sıralamasında en üst basamaklarda yer alan bazı devlet üniversiteleri (Boğaziçi, ODTÜ, Gazi Üniversitesi) yeni kayıt yaptıran öğrencilerinden yabancı dil yeterliklerini belgelemelerini isterlerken YDS ve YÖKDíL sınav sonuçlarını kabul etmeyip içerisinde yazma, konuşma ve dinleme becerilerinin ölçüldüğü uluslararası geçerliğe sahip sınavların (TOEFL, IELTS vb.) sonuçlarını kabul etmektedirler (Aydın vd., 2017). Bu durum da halihazırda Türkiye'de yabancı dil yeterliği ölçümünde kullanılan ve ağırlıkla çoktan seçmeli sorulara doğru cevapları bulma veya boşluklara gelecek doğru ifadeleri tanıma şeklinde maddeler içeren dil sınavlarının yabancı dil yeterliliğini ölçmeye yetmeyebileceği gerçeğini ortaya çıkarmaktadır. Öte yandan çoğunlukla bilişsel düzeyde tanıma ve anlama basamaklarında sorular içeren dil sınavlarının Türkiye'deki yabancı dil eğitimi anlayışı ve yabancı dil sınavlarına giren adayların yabancı dil öğrenim yöntem ve tercihleri üzerindeki etkileri ve sonuçları araştırılmalı ve tartışılmalıdır.

\section{Sınav Etkisi}

Test etkisi veya sınav etkisi olarak tanımlanan olgu eğitimde uzunca bir süredir birçok araştırmacının (Alderson ve Wall, 1986; Ching, 2009; Fulcher ve Davidson; 2007; Hawkey, 2006; Külekçi, 2016; McEwen, 1995; Özmen, 2011; Polat, 2018; Rahimi ve Nazhand, 1992; Shepard, 1997; Stobart, 2003; Sukyadi ve Mardiani, 2011) ele aldığı ve sınavların eğitim ve öğretime dolaylı ya da dolaylı olmayan yollardan yaptığı etkidir. Sınav etkisinin öğretim yöntemleri, materyaller, öğrenim çıktıları ve hatta öğrenci motivasyonu üzerinde olumlu izler bırakabileceği gibi olumsuz izler de bırakabileceğinin altını çizmek gerekir. Alderson (1992) sınav etkisinin pozitif, negatif veya aynı anda her ikisi de olabileceğini belirtmiş ve bu etkilerin araştırılarak sınavların negatif etkilerin önüne geçecek tedbirlerin alınması gerektiğini belirtmiştir. Öyle ki, eğitim süreçlerinde öğrenci motivasyonunu canlı tutmak ve onları daha çok çalışmaya, araştırmaya ve okumaya güdülemek için sınav yapmanın olumlu etkileri yadsınamaz. Çoğu öğrenci sırf sınavlar sayesinde eğitim programının içinde kalıp, doğru zamanda doğru bilgileri edinebilmekte ve böylelikle bilinçli olsun ya da olmasın hedeflenen öğrenim çıktılarını sergileyebilmektedir ve bu gerçeklik sınavların pozitif etkileri konusunda iyi bir örnek olabilir. Diğer yandan sınavların negatif etkileri düşünüldüğünde öğrencilerin sırf iyi notlar alabilmek adına bu sınavlara çalıştıkları ve bu yüzden öğrenmenin kalıcı olmayabileceği ve eğitim süreciyle amaçlanan öğrenim çıktılarının gerçek anlamda elde edilemeyebileceği de söylenebilir. Green (2007) testlerin bu olumsuz tarafının altını çizmiş ve testin içeriğinin ve soru tipinin sözü edilen olumsuz etkileri yaratacak tarzda olmaması gerektiğini söylemiştir. Özellikle çoktan seçmeli testlerde görülen ve birçok eğitimcinin şikâyet ettiği sorun da buna benzerdir. Öğrenci sınav esnasında tanıma veya hatırlama boyutunda sorulara verdiği cevaplarda iyi performans gösterirken analiz veya sentez boyutunda sırf eski sınav alışkanlıkları yüzünden yeterli performansı sergileyememekte ve bu durum da akademik başarısını olumsuz yönde etkilemektedir (Ching, 2009). Dahası, çoktan seçmeli sınavların sonuçlarına dayanılarak verilen ölçme kararları zaman zaman içi boş, yanlış kararlar olarak eğitimcilerin önüne çıkabiliyor çünkü sırf test alışkanlıkları kazandığı için çoktan seçmeli sınavlarda başarı gösteren adayların sayısı yadsınamayacak kadar fazlalaşmıştır (Hatipoğlu, 2016).

Türkiye'de uygulanan çoktan seçmeli sınavların etkileri üzerine yapılan çalışmalar genellikle bu tarz sınavların olumsuz taraflarını öne çıkarmıştır. Kamu Personeli Seçme Sınavı'nın etkilerini araştıran Özmen (2011) bu sınavların etkilerinin eğitsel ve sosyal etkiler başlığı altında değerlendirilmesi gerektiğini savunmuş ve eğitsel anlamda çoktan seçmeli sınavların geçerliğinin oldukça göreli bir yerde durduğunu ve tartışmaya açık olduğunu belirtmiştir. Her yıl binlerce adayın kamu kuruluşlarında işe girebilme adına girdikleri bu sınavın geçerliğine inanmaması ve neyi ölçtüğü konusunda şüphe duyması oldukça rahatsız edicidir. Öte taraftan sınava hazırlık için harcanan zaman, emek ve para göz önüne alındığında ve bu esnada adayların yaşadıkları stres ve motivasyon sıkıntı da hesaba katıldığında sınavın sosyal yönden de etkilerinin oldukça olumsuz yönde olduğu aktarılmıştır (Özmen, 2011). Bu çalışma özellikle sınavların sadece eğitsel etkilerinin değil psikolojik ve sosyal etkilerinin de olduğunu ve değerlendirme yaparken tümünün dikkate alınması gerektiğini göz önüne sermiştir. 
Türkiye'de yapılan yabancı dil sınavlarının olası etkileri konusunda alan yazından elde edilen sınırlı sayıdaki çalışmalardan ilki Akpınar ve Çakıldere (2013) tarafından o yıllarda yapılan ancak 2013 itibarıyla kaldırılan KPDS (Kamu Personeli Dil Sınavı) ve ÜDS’nin (Üniversitelerarası Kurul Yabancı Dil Sınavı) sınav etkileri üzerine yapılmış tarama türünde bir çalışmadır. Çalışmada adı geçen çoktan seçmeli yabancı dil sınavlarının (KPDS ve ÜDS) adayların yabancı dil öğrenirken geliştirmek durumunda oldukları 4 beceriden (hedef yabancı dilde yazma, okuma, konuşma ve dinleme) sadece "yabancı dilde okumak" üzerinde olumlu etkileri olduğunu diğer tüm beceriler üzerinde olumsuz etkilerinin gözlemlendiğini belirtmişlerdir. Türkiye'de uygulanan çoktan seçmeli dil sınavlarında konuşma, dinleme ve yazma etkinliklerinin yer almaması sınava giren adayların bu becerileri önemsememesi ve üzerinde durmaması sonucunu ortaya çıkarmıştır ki, bu dil öğrenen bireylerin hiçte yönelmemesi gereken bir yoldur. Poonpon (2010) dil yeterliğinin belirlenmesinde konuşma ve yazma sınavlarının son derece önemli olduğunu, bu sınavların yapılmasının eğitim kurumları için pahalı ve zor olmasına karşın öğrenciler üzerindeki olumlu etkileri göz önünde bulundurulduğunda büyük önem taşıdığını belirtmiştir. Dolayısıyla Türkiye'de yapılan çoktan seçmeli yabancı dil sınavları içermedikleri konuşma, yazma ve dinleme becerilerine yönelik sorular yüzünden bu sınavlara giren adayların yabancı dil öğrenme içerik ve yöntemleri konusunda oldukça yön belirleyici olabilirler. Eğer bir sınavda hiç dinleme, yazma ve konuşma içerikli soru bulunmuyorsa adaylar neden bu gibi becerileri edinmek için zaman ve çaba harcasınlar ki?

Türkiye'deki yabancı dil sınavlarının olası etkileri konusunda yapılan bir diğer çalışmada Yavuzer ve Göver (2012) Nevşehir ilindeki akademisyenlerden derledikleri örneklem üzerinde yaptıkları araştırmada çoktan seçmeli dil sınavlarının akademisyenlerin kendi disiplinlerinde çalışma yapmak, araştırmalarına zaman ayırmak ve asıl konsantre olmaları gereken konulara konsantre olmak yerine dil testleri ve bu testlerde işe yarayacak test çözme metotlarına ağırlık verdiklerini belirtmişler ve bu durumun olumsuz psikolojik etkiler yarattığının altını çizmişlerdir. Hatta, bu sınavlardan istedikleri sonuçları alamayan akademisyenlerin zaman kaybettiklerini ve hem maddi hem manevi sıkıntılar yaşadıklarını iletmişlerdir. Bu çalışma aslında Türkiye'de yabancı dil yeterliği ölçümünde sorunun merkezi dil sınavlarına girilmeden daha önce başladığını, ortaokul ve lise yıllarında verilen yabancı dil dersleri sonucunda yapılan ölçme ve değerlendirme uygulamalarının yeterli ve geçerli olamayabileceğini sonuçları ve bunların yansımalarıyla göstermektedir.

Benzer bir olumsuz sınav etkisi Külekçi (2016) tarafından YDS'nin sınav etkileri konusunda yapılan çalışmada dile getirilmiştir. Araştırmacı Bachman ve Palmer'ın (1996) hazırladığı yabancı dil bilme kriterlerine uygun olarak bir çerçeve dahilinde YDS'nin içerdiği, soru tipleri ve bölümlerini incelemiş ve bu tarz bir sınavın olası etkileri konusunda analizler yapmıştır. Çalışmada sınava girenlerin görüşleri alınmamış sadece sınav sorularının yol açabileceği olası durumlar konusunda analizlere yer verilmiştir. Külekçi'nin (2016) altını çizdiği sonuçlar arasında YDS'nin adaylar üzerinde yabancı dil için daha fazla çalışma ve soru çözme gibi kelime ve okuma becerilerine dönük pozitif etkilerinin olduğu belirtilmiştir. Bunun yanı sıra YDS'ye hazırlanmanın adayların test tekniklerine çok fazla zaman ayırıp dili sadece belirli dilbilgisi kuralları ve kelime bilgisinden ibaretmiş gibi algılamalarına yol açtı̆̆ı ileri sürülmüştür. Bu saptamada açıkça Gür'ün (2012) bir yerde eğitim nasıl yapılıyorsa ölçme ve değerlendirmesi de ona uygun yapılıyordur söyleyişini haklı çıkarır niteliktedir. Bunun tersi de doğrudur, sınavların içeriği ve uygulaması nasılsa ilgili eğitimin içeriği ve amaçları da o doğrultudadır çünkü eğitim programı ve ölçme değerlendirme hep iç içe ve birbirini tamamlar şekilde gerçekleşir (Fulcher ve Davidson, 2007). Mirici (2003) Türkiye'deki yabancı dil sınıflarında sıklıkla görülen dilbilgisi ve kelime öğretiminin okullardaki sınavlara da yansıdığını, sınav içeriklerinin çoğunlukla dilbilgisi ve kelime bilgisi ölçme üzerine kurgulandı̆̆ını ve bunun zincirleme bir şekilde merkezi dil sınavlarına da etki ettiğini belirtmiştir. Nitekim çoktan seçmeli sınavlarda ağırlıkla çeviri, dilbilgisi ve kelime sorusunun bulunmasının temel nedenlerinden biri de Türkiye'deki yaygın dil eğitim yöntemleridir (Özmen, 2011). Eğitim yöntemleri sınavları, sınavlar da dönüp eğitim yöntemlerini etkiler ve çok doğaldır ki herhangi birindeki olumsuzluk ve eksiklik şüphesi öbürüne de yansıyacaktır.

Son olarak Akın (2016) 2013-2015 yılları arasında yapılan YDS sınavlarının soru tip ve içeriklerine eğilmiş ve bu soruların dağılımı ve akademisyenlerin çalıştıkları disiplinler göz önüne alındığında içeriklerinin işlevsel olup olmadıklarını incelemiştir. Çalışma sonunda soru dağılımının farklı akademik disiplinlere hitap edecek çeşitlilikte olmadığı, soru tiplerinin yabancı kelime ezberi ve dilbilgisi kuralı bilme gibi becerileri ön plana çıkarırken dinleme, yazma ve konuşma becerilerinin göz ardı edildiği ve bunun da adayların yabancı dil öğrenme algılarını olumsuz etkilediği ortaya çıkarılmıştır. Özetle bütün bu çalışmaların da gösterdiği gibi Türkiye' de halihazırda uygulanan yabancı dil sınavları adayların hedef dilde konuşma, yazma ve dinleme becerilerini ölçmemekte ve bu durum adayların yeterliğini ispatlasa dahi yabancı dilde etkili iletişim kurabileceği konusunda şüphe duyulmasına yol açmaktadır. Konuya ilişkin çalışmalar genellikle yabancı dil sınavlarının içerikleri ve adaylar üzerindeki psikolojik ve sosyal etkileri üzerine yoğunlaşmış, bu sınavların Türkiye'deki yabancı dil eğitimine olan pedagojik etkileri üzerinde pek durulmamıştır. YDS ve YÖKDIL gibi sınavların içerikleri göz önüne alındığında daha ziyade çeviri becerisine yönelik çok sayıda kelime ve bağıı yapıların sorulduğu, karmaşık dilbilgisi kurallarının yer aldığı sorular içermeleri beraberinde adayların dil öğrenme eğilimlerinin sadece bu ve benzeri becerilerini geliştirme yönüne kaymasına neden olmaktadır. Bu durum yabancı dil eğitim yöntemlerini, kullanılan dil materyallerinin içeriğini, yabancı dildeki hedef becerileri ve bireylerin yabancı dil öğrenimine karşı tutumlarını etkileyebilmektedir. Bu çalışmanın amacı YDS ve YÖKDIL gibi çoktan seçmeli dil sınavlarının yabancı dil eğitim yöntem, materyal ve yabancı dil becerileri üzerindeki pedagojik etkilerinin belirlenmesidir. Bu temel amaç ışığında çalışmada aşağıda yer alan sorulara yanıt aranmıştır:

YDS ve YÖKDIL gibi çoktan seçmeli dil sınavlarının Türkiye'deki yabancı dil eğitim / öğrenim 
1. yöntemlerine etkileri nelerdir?

2. materyallerine etkileri nelerdir?

3. ortamlarına etkileri nelerdir?

4. çıktılarına etkileri nelerdir?

\section{YÖNTEM}

Bu çalışmada 2018- 2019 yılları arasında Eskişehir il'indeki 3 devlet üniversitesinden toplam 43 akademisyenin katılımıyla YDS ve YÖKDiL gibi çoktan seçmeli yabancı dil sınavlarının yabancı dil eğitimi üzerine olası etkileri ortaya çıkarmak amaçlanmış ve katılımcıların konu hakkında görüşlerini olabildiğince detaylı ve gerekçeleriyle yansıtabilmek adına nitel araştırma yöntemi tercih edilmiştir. Nitel yaklaşım katılımcıların araştırma konusuyla ilgili algılarını ve olayların doğal ortamda gerçekçi ve bütüncül bir biçimde ortaya konmasına yönelik bulguları açığa çıkarmak adına oldukça işlevsel bir yöntem olarak tanımlanır (Yıldırım ve Şimşek; 2011). Bu çalışma tipinde bir soruna ilişkin boyutlar (zaman, bağlam, taraflar, vb.) bütüncül bir bakış açısıyla ele alınır. Mesele irdelenirken tarafların söz konusu durumdan nasıl, niçin etkilendikleri ve söz konusu durumun görüldüğü toplum, hâkim görüşler, alışkanlıklar ve ilgili sistemler ele alınarak derinlemesine ve nedenleri ortaya koyan bir anlama hedeflenir (Yıldırım ve Şimşek, 2011). Araştırma deseni olarak nitel yaklaşım türlerinden durum (örnek olay) çalışması tercih edilmiş ve örneklem türü katılımcılarla yapılacak görüşmelerin kimlerle yapılabileceği, zamanı ve süresi açısından tamamen katılımcıların gönüllülüğüne dayalı olduğundan gönüllü örnekleme olarak belirlenmiştir.

\section{Çalışma Grubu}

Araştırmaya Eskişehir ilinde yer alan Anadolu Üniversitesi, Osmangazi Üniversitesi ve Eskişehir Teknik Üniversitesi'nden 15 erkek 28 kadın olmak üzere toplam 43 akademisyen gönüllü olarak katılmıştır. Akademisyenlerin unvanlarına göre dağılımı 7 Profesör Dr., 6 Doçent Dr., 11 Öğretim Üyesi Dr. ve 19 Öğretim Görevlisi şeklindedir. Araştırmaya katılan akademisyenlerden 11'i Sosyal Bilimlerde, 10'u Fen Bilimlerinde, 8'i Eğitim Bilimlerinde ve diğer 14 tanesi diğer bilim dallarında (sağlık bilimleri, spor bilimleri, güzel sanatlar vb.) çalışan öğretim elemanlarıdır. Çalışmaya katılan akademisyenler en az bir kere KPDS, ÜDS, YDS veya YÖKDIL sınavlarından herhangi birine girmiştir. Çalışmanın odağı YDS ve YÖKDiL sınavlarının etkilerini ortaya çıkarmak olmasına karşın KPDS ve ÜDS sınavlarına girmiş olan katılımcıların da söz konusu sınavların aynı kurum, aynı soru içerik ve tipleri benimsenerek hazırlandığı göz önünde bulundurulduğundan ayrım gözetmeksizin adı geçen tüm sınavlara girmiş olan katılımcıların görüşleri alınmıştır. Çalışmaya katılan akademisyenlerin tamamı (akademik yükselme, lisansüstü programlara kayıt veya yabancı dilde ders vermek için) kendilerine gerekli olan yabancı dil yeterliklerini (bu yeterlik puanları akademik unvana göre zaman içerisinde farklılıklar göstermiştir) adı geçen sınavlardan birinden aldıkları yabancı dil sonuçlarına göre belgelemişlerdir. Katılımcıların tamamı yabancı dil olarak İngilizceden sınavlara girmişlerdir ve katılımcıların hiçbiri İngiliz Dili Eğitimi alanından değildir.

\section{Veri Toplama Aracı}

Akademisyenlerin YDS ve YÖKDiL sınavlarının yabancı dil eğitimi üzerine etkileriyle ilgili görüşlerinin araştırıldığı bu çalışmanın verileri araştırmacı tarafından 4 aşamalı bir süreç sonunda geliştirilen yarı yapılandırımış görüşme formu kullanılarak toplanmıştır. Yarı yapılandııılmış görüşme biçiminde görüşmede sorulacak soruların yalnız bir kısmı yapılandırımış olarak sorulur, soruların yapılandırılmamış kısmı katılımcının yapılandırılmış sorulara verdiği cevaplara ve alınan tepkilere göre görüşme esnasında belirlenir (Aziz, 1994). Bir diğer deyişle veri toplama esnasında araştırmacının hareket alanını artırmak amacıyla görüşme esnasında vereceği tepkilere dayalı olarak sorular sorulabilir zira açık uçlu görüşme formu bu duruma uygun biçimde hazırlanmış olur ve bu sayede katılımcıdan daha fazla anlamlı veri alınabilir (Aypay vd., 2014, s. 151). Görüşme formu hazırlanırken aşağıdaki aşamalar takip edilmiştir:

1. Araştırma sorusunun tanımlanması, araştırma amacı ve içeriğinin belirlenmesi, alan yazın taraması.

2. Görüşme formunda yer alacak maddelerin yazımı ve taslak oluşturulması.

3. Hazırlanan görüşme formu taslağında yer alan maddeleri uzman görüşüne sunma ve revize etme.

4. Görüşme formu taslağını ön uygulamada deneme ve sonuçlara göre revize edip son halini verme. 
Gerçekleştirilen alan yazın taraması sonrasında oluşturulan 17 maddelik görüşme formu taslağı 4 kişiden oluşan akademisyen grubunun görüşlerine sunulmuştur. Uzman görüşü için yardım alınan akademisyenlerin tamamı Profesör Dr. unvanına sahip olup iki tanesi İngiliz Dili Eğitimi, bir tanesi Türk Dili ve Edebiyatı ve bir tanesi de Eğitim Bilimleri alanında çalışan öğretim üyeleridir. Uzman görüşü alındıktan sonra 3 madde formdan çıkarılmış, 5 madde üzerinde değişikliğe gidilerek görüşme formu 14 madde olarak ön uygulamaya tabi tutulmuştur. Ön uygulama safhasında farklı disiplinlerden farklı unvanlarda gönüllü 3 akademisyenle görüşmeler gerçekleştirilmiştir. Ön uygulama sonrasında görüşmelerin ortalama 20-25 dakika civarında süre aldığı ve ortaya çıkan 14 maddelik görüşme formunun işlevsel olduğu uygulamaya katılan 3 akademisyenin ortak görüşüyle onaylanmıştır.

\section{Veri Toplama Süreci}

2018-2019 yılları arasında gerçekleştirilen bu çalışmaya toplam 43 gönüllü akademisyen katılmıştır. Veri toplamak için katılımcılarla 20-25 dakika süren yüz yüze görüşmeler yapılmış ve tüm görüşmeler katılımcıların izni dahilinde dijital ses kayıt cihazıyla kaydedilmiş ve elde edilen ses dosyaları herhangi bir kaybı önlemek için araştırmacı tarafından iki ayrı bellekte saklanmıştır. Veri toplama aşamasında katılımcılara çalışmanın amacı aktarılmış, beyan edecekleri görüşlerin sadece bu çalışma için kullanılacağı, önemli noktalarda görüşlerinden alıntı yapılırken isim ve kimlik belirtmeden katılımcı kodları kullanılarak bilgi aktarılacağı söylenmiştir. Katılımcıların görüşme esnasında daha rahat olabilmeleri amacıyla kamera kaydı değil ses kaydı tercih edilmiş ve katılımcıların tamamı görüşme kaydının bu şekilde olmasına görüşme öncesinde onay vermiştir. Katılımcılardan toplanan veriler daha sonra araştırmacı tarafından bilgisayar ortamında yazıya dökülmüş ve analize hazır hale getirilmiştir.

\section{Veri Analizi}

Araştırmadan elde edilen verinin analizinde betimsel analiz yöntemi kullanılmıştır. Betimsel veri analizinde farklı katılımcıların aynı sorular hakkındaki kişisel düşünceleri görüşmeci tarafından alınarak tematik bir çerçeve içerisinde kodlanır, gruplanır ve yorumlanır. Betimsel analiz dört aşamadan oluşur (Altunışık vd., 2010, s:322):

1. Betimsel analiz için bir çerçeve oluşturma: Çalışmada yer alan akademisyenler ile gerçekleştirilen ve ses kaydı alınan görüşmeler sonrasında araştırmacı tarafından yazıya dökülmüştür. Yazılı hale getirilen veri bir sonraki aşama için düzenlenmiştir.

2. Tematik çerçeveye uygun olarak verilerin işlenmesi: illk aşamada yazıya dökülen ve düzenlenen verinin içeriğinden hareketle araştırma soruları çerçevesinde temalar oluşturulmuştur.

3. Bulguların tanımlanması: Oluşturulan temalar etrafında akademisyenlerden toplanan veri gruplandırılmış ve gerekli yerlerde alıntı yapılabilmesi için düzenlenmiştir.

4. Bulguların yorumlanması: Son aşamada elde edilen bulguların, alan yazınla ilişkilendirilmesi, açıklanması ve yorumlanması yapılmıştır.

Araştırmada elde edilen akademisyen görüşleri kodlanırken katılımcıyı temsilen "K" ve sıra numarası olarak rakamlar kullanılmıştır. Örneğin "K12" kodu 12 numaralı katılımcının görüşlerini yansıtırken kullanılmıştır.

\section{BULGULAR}

Akademisyenlerin YDS ve YÖKDIL sınavlarının yabancı dil eğitimi üzerine etkileriyle ilgili görüşlerinin araştırıldığı bu çalışmanın bulguları araştırma soruları da dikkate alınarak, katılımcıların YDS ve YÖKDiL gibi çoktan seçmeli dil sınavlarının: "dil eğitimi yöntemlerine etkileriyle ilgili görüşleri", "dil eğitimi materyallerine etkileriyle ilgili görüşleri", "dil eğitimi ortamlarına etkilerine ilişkin görüşleri" ve "dil öğrenimi çıktılarına etkileriyle ilgili görüşleri" olmak üzere dört ana tema etrafında değerlendirilmiştir. Araştırmanın amacı ve cevap aradığı sorular ışığında derlenen bulgular gerekli görülen yerlerde katılımcılardan doğrudan alıntılar yapılarak sırasıyla sunulmuştur.

\section{Akademisyenlerin YDS ve YöKDiL sınavlarının dil eğitimi yöntemlerine etkileriyle ilgili görüşleri}

Araştırma verisinin toplandığı yüz yüze görüşmelerde Eskişehir ilinde yer alan Anadolu Üniversitesi, Osmangazi Üniversitesi ve Eskişehir Teknik Üniversitesi'nden 43 akademisyene ilk olarak YDS ve YÖKDiL gibi çoktan seçmeli dil sınavlarının dil eğitimi yöntemlerine etkileriyle ilgili görüşleri sorulmuştur. Katılımcıların bu soruya verdikleri yanıtlar; (1) çeviri yapmaya ağırlık verme, (2) kelime ezberleme, (3) dilbilgisi kurallarına ağırlık verme ve (4) test tekniklerine ağırlık verme olmak üzere toplam dört alt tema altında toplanmıştır. YDS ve YÖKDiL sınavlarının yabancı dil eğitim yöntemleri üzerindeki etkileri katılımcıların büyük çoğunluğu tarafından (39 katılımcı) olumsuz olarak tanımlanmıştır.

Katılımcıların çoğunluğu (35 akademisyen) Türkiye'de yabancı dil seviye belirleme amacıyla uygulanan YDS ve YÖKDiL gibi çoktan seçmeli dil sınavlarının öncelikli hedefinin adayların hedef dil yapılarını tanıma, anlama ve hedef dilden ana dile veya ana 
dilden hedef dile çeviri yapabilme becerisini ölçtüğünü ve bu gerçekliğin kendi yabancı dil eğitimlerini de çok etkilediğini belirtmişlerdir. Bu durumun yabancı dil eğitimine olumlu olarak katkı verdiğini düşünen akademisyenler (6 katılımcı) olduğu gibi olumsuz etki ettiğini düşünenlerin sayısı oldukça fazladır (31 katılımcı). Bir grup akademisyen (6 katılımcı) ise çeviri konusunda sınavların hem olumlu hem de olumsuz etkileri olduğunu dile getirmişlerdir. Öncelikle, çeviriye ağırlık vermenin dil eğitimini olumlu etkilediğini düşünen katılımcılardan gelen görüşlerden birinde katılımcı: "Okuma parçaları ve çeviri soruları yüzünden çeviri yapmaya o kadar alışmıştım ki ne zaman ingilizce bir şeyler görsem hemen otomatikman kafamda çevirmeye ve toparlayıp anlamaya çalışıyordum ve bu durum sonrasında ingilizce makale okurken çok işime yaradı. (K8)" bilinçli olmadan yabancı dilde çeviri yaparak ciddi miktarda pratik yapma şansı bulduğunu ifade etmiş, başka bir katılımcı ise: "Soru çözerken çeviri yaptıkça farklı kelimeler, farklı yapılar karşıma çıkıyor ve o merakla hemen açıp kaynaklardan inceliyordum. Bu sayede bayağı kelime ve gramer yapısı öğrenmiştim. (K17)" diyerek çeviri yapmanın kelime ve dilbilgisi konusunda kendisini araştırmaya yönlendirdiğinden dil öğrenimine katkıda bulunduğunu ifade etmiştir. Öte yandan çeviri yapmanın dil eğitimini olumsuz etkilediğini düşünen katılımcılardan gelen görüşlerden bazıları çeviri yapmanın yarar değil zarar verdiği görüşündeydi. Bu konuda görüş bildiren bir katılımcı: "Okuma parçalarında okumayı değil çevirisini ön plana çıkartıyorsunuz ve bu okuduğunuzu anlamanızı ve parçaları bir araya getirmenizi engelliyor. (K3)" derken okuma anlama konusunda çeviri alışkanlığının kişiyi duraksattığını ve işin zorlaştırdığını dile getirirken farklı bir diğer katılımcı: "Ingilizce herhangi bir şeyi gördügünüzde veya duyduğunuzda onu çevirmeye çalışıyor ve bu esnada bilmediğiniz bir kelimeyle karşılaştığınızda öylece kalıyorsunuz çünkü YDS'de özellikle kilit bazı kelimelerin anlamı üzerine soru odaklanıyor ve bir o kelimeyi bilmiyorsanız soruyu çözemiyorsunuz. (K27)” çeviri alışkanlığı yüzünden bağlamdan anlam çıkarma gibi bazı üst becerilerin ötelendiğini ve bunun önemli bir sorun olduğunu ifade etmiştir. YDS ve YÖKDiL sınavlarına hazırlanırken çeviriye ağırlık verme konusunda bir diğer katılımcı ise araştırma konusu ile ilgili başka bir boyutu dile getirmiştir: "Her konuda ihtiyaçların değiştiği bu zamanda yabancı dil becerileri konusundaki ihtiyaçlar da değişmiştir. Eskiden çeviri çok önemli görülüyormuş olabilir ama artık iletişim arttı ve daha hızlı. Bizler bir Ingilizce mail veya mesaj aldığımızda tedirgin oluyoruz. Ne yapacağız nasıl karşılık vereceğiz diye ve mutlaka iyi bilen birilerinden yardım alıyoruz. Olay böyleyse çeviri bilsek ne olacak ki? (K33)." Son olarak çevirinin hem olumlu hem de olumsuz etkilerinin olduğunu düşünen bir katılımcı: "Çeviriyi nerede ve ne zaman kullanacaksınız kısmı bence önemli, eğer yazma ve okuma ile ilgili bir durumsa evet çeviri becerileri işe yarıyor ancak daha simültane bir yabancı dil kullanımı varsa o zaman çeviri alışkanlıkları sizi yavaşlatabilir. (K5)" örneğini vererek çeviri konusunda farklı artı ve eksi yönlerin olduğunu belirtmiştir.

YDS ve YÖKDiL gibi çoktan seçmeli dil sınavlarının dil eğitimi yöntemlerine etkileriyle ilgili ikinci alt tema olan kelime ezberleme konusunda da çeviri konusunda olduğu gibi farklı görüşlerle karşılaşılmıştır. Katılımcıların bir kısmı (8 akademisyen) kelime YDS ve YÖKDIL gibi dil sınavları sayesinde ciddi miktarlarda kelime öğrendiklerini ve buna sınavlardaki kelime bilgisi sorularından ötürü yaptıkları kelime ezberine borçlu olduklarını bildirmişlerdir. "ingilizce makale okurken şunu fark ettim ki dilleri hiç öyle her gün karşılaşabileceğiniz sadelikte ve basitlikte değil. Hem çok karmaşık dil yapıları var hem de akademik kelimeler ve eğer bu kelimelere önceden çalışmamışsanız metinleri anlamada büyük zorluk çekiyorsunuz. YDS'ye çalışırken ezberlediğim bir grup kelime öyle çok işime yaradı ki inanamazsınız. (K13)". Bir başka katılımcı ise sınavlar sayesinde yabancı dil çalışmaya motive olduğunu belirtmiş ve şöyle eklemiştir: "Valla beğenseniz de beğenmeseniz de bu sınavdan geçmek için kelime bilmeniz bunun için de eğer çok okumuyorsanız ezber yapmanız gerekiyor ve bu da kelime dağarcığınızı şu veya bu şekilde olumlu yönde etkiliyor. (K2)”. Buna karşın kelime ezberinin dil öğrenmeye belirgin bir faydası olmadığını ve hatta kimi durumlarda zarar dahi verebildiğini söyleyenlerin sayısı çok daha fazladır (24 akademisyen). Kelime ezberinin ne sınavda ne de sonrasında bir işe yaramadığını ve onca zaman boşuna kelime ezberi yaptığını ileten bir katılımcı şöyle devam etmiştir: "Yanarım onca kelime defteri, listesi yaptığıma yanarım. Sık karşılaştığım kelimeleri o deftere yazar zaman zaman ezberlemeye çalışırdım ancak çok sonra anladım ki bu zaman kaybı ve pratikte hiç işe yaramıyor. (K1)". Başka bir katılımcı ise kelime ezberinin dil öğrenirken zararlı olabileceğini şu örnekle dile getirmiştir: "Kelime ezberlerken o anki anlamı sizin odağınız oluyor ama bir kelimenin tek bir anlamı mı var? Siz o anlamı ezberliyor ve aynı kelimenin farklı anlamla kullanıldığı bir yerde ezberiniz yüzünden hata yapıyorsunuz. Mesela book kitap demek ve ben onun yer ayırtma anlamına geldiğini bilmediğim bir parçada ne çok sıkıntı çekmiştim. (K16)".

Akademisyenlerin YDS ve YÖKDiL sınavlarının dil eğitimi yöntemlerine etkileriyle ilgili görüşleri içerisinde bir diğer alt tema olan dilbilgisi kurallarına ağırlık verme konusunda akademisyenlerin neredeyse tamamı olumsuz etkilediği konusunda hem fikir olmuşlardır (42 akademisyen). Yabancı dil öğrenirken dilbilgisi kurallarının çok önemli olduğunu ve dilbilgisi kuralarını çalışmanın dil eğitimine büyük katkısı olduğunu düşünen tek bir akademisyen çıkmış ve görüşünü şu şekilde dile getirmiştir: "Bir şeyi öğretebilmeniz için bir sistematiğe oturtmanız gerekir ve bence gramer kuralları dil öğrenmenin sistematiğidir. Bu yüzden okullarda vs. hep dil öğretilirken önce gramerden başlanır ve bu sınavlara da yansımış bir durumdur. Değil mi? (K29)”. Ancak diğer katılımcılar dilbilgisi kurallarının sınavlarda sıkça sorulması ve önemle üzerinde durulmasının dil öğrenimlerine katkısı olmadığını ve hatta kurallar yüzünden birçok konuda tedirgin olduklarını ve yabancı dilde iletişime yanaşmadıklarını ifade etmişlerdir. "KPDS ve ÜDS yüzünden neredeyse tüm Ingiliz gramerini öğrendim ve şu an bende hepsi sıfır. Sınavı geçtik ve hepsi unutuldu neden? Çünkü çalışırken anlamlı olduğunu düşünmüyorsunuz, sadece sınav geçmek ve onca "past" bilmem neyin "if"lerin falan hiç tozu bile kalmıyor çünkü anlamsız ve zaman kaybı. (K21)". İletişim kurarken sırf bu kurallarla ilgili takıntılarını bir türlü yenemediğini belirten 
başka bir katılımcı ise: "Ne zaman bir kongreye gitsem ödüm kopuyor bana soru soracaklar ve bende cevap verirken abuk sabuk bir gramer hatası yapacağım diye. O kadar kısa zamanda her şeyi bir arada düşünmek öyle zor oluyor ki ve ben bu yüzden büyük sıkıntı yaşıyorum. (K26)." diyerek dilbilgisi kurallarının üzerinde çok durulmasının kendi yabancı dil kullanımını ne denli etkilediğini yansıtmıştır. Hawkey (2006) dil sınıflarında yoğun dilbilgisi eğitiminin bu kuralların içselleştirilmediği durumlarda sözlü ve yazılı dil kullanımına olumsuz etki edebileceğini ve çekingenliğe yol açabileceğini belirtmiştir. Nitekim bu durum başka bir katılımcı tarafından şu şekilde ifade edilmiştir: "Ne zaman Ingilizce bir şeyler yazacak ya da söyleyecek olsam birkaç dakika öncesinden kafamda hazırlamam, gramerini falan düzenleyip kontrol etmem gerekiyor. Bunu yapmazsam konuşamam, kendimi rahat hissetmem çünkü, bu gramere bir taktın mı kurtulamıyorsun işte. (K38)".

YDS ve YÖKDiL sınavlarının dil eğitimi yöntemlerine etkileriyle ilgili görüşler içerisindeki son alt tema test tekniklerine ağırlık verilmesi olarak belirlenmiş ve bu konuda görüş bildiren tüm katılımcılar bu durumun dil öğrenme sürecini olumsuz yönde etkilediğini belirtmişlerdir (23 akademisyen). Dil öğrenirken amacın sınav geçmek olmaması gerektiğinin altı çizilirken YDS ve YÖKDIL sınavlarının soru içeriklerinin oldukça zorlayıcı olduğu ve belli taktikler gerektirdiği dile getirilmiştir. "Hep formüller yazardı hocamız bizi çalıştırırken şunu gördüğünde şöyle yap, virgül varsa bunu seç gibi. Niye böyle yaptık bilmiyorum ama matematik öğrenir gibi dil mi çalışılır? (K5)". Dilbilgisi kurallarının belli formüller ve kısa yollar halinde verilmesinin dil öğrenimini olumsuz etkilediğini dile getiren bir diğer katılımcı: "Biz gramer kurallarını sadece tanımak ve gördüğümüzde doğru seçeneği bulmak için öğrendik ve sonuçta sınavı bir şekilde geçtik ama gelin görün ki ortada hiçbir şey yok. Dili biliyor muyuz hayır, yeterliğimiz var mı evet, komik yani. (K11)" diyerek aslında test tekniklerinin sadece bu sınavlarda işe yarayacak geçici çözümler olduğunu ve yabancı dil öğrenme sürecine hiçbir katkılarının bulunmadığını dile getirmiştir.

\section{Akademisyenlerin YDS ve YöKDiL sınavlarının dil eğitimi materyallerine etkileriyle ilgili görüşleri}

Araştırma sorularından ikincisi YDS ve YÖKDiL sınavlarının yabancı dil eğitiminde kullanılan materyaller üzerindeki etkilerini belirleme üzerinedir. Çalışmaya katılan akademisyenlerin bu soruya verdikleri yanıtlar (1) Dil testleri, (2) Dilbilgisi kaynakları ve (3) Görsel işitsel malzeme kullanılmaması olmak üzere 3 alt tema etrafında gruplandırılmıştır. YDS ve YÖKDiL sınavlarının yabancı dil eğitim materyalleri üzerindeki etkileri katılımcılarca çoğunlukla (36 katılımcı) olumsuz olarak tanımlanmıştır. Akademisyenlere YDS ve YÖKDiL sınavlarına girmeden önce yabancı dille ilgili çalışmalarında ne tür kaynaklar kullandıkları ve bu kaynakların dil eğitimlerine ne ölçüde katkıda bulunduğu sorulduğunda katılımcıların büyük çoğunluğu (35 katılımcı) sınavların içeriği ve soru tipi yüzünden yabancı dil eğitimlerinde daha ziyade çoktan seçmeli yabancı dil testlerinden faydalandıklarını belirtmişlerdir. Bu testlerin pratikte sınavı geçebilmek adına çok işe yaradığını belirten katılımcılardan biri: "Aynı üniversite sınavı mantığı, YDS için ne kadar çok soru çözersen o kadar pratik kazanıyorsun. Hep benzer çeviriler, benzer cümle tamamlamaları falan çıkıyor. (K40)" diyerek YDS ve YÖKDiL hazırlığı için neden testlere ihtiyaç duyulduğunu cevaplarken başka bir katılımcı: "Önceleri ciddi ciddi online gazete falan okuyordum, pratikte katkısı olduğunu düşünerek. Hatta film falan izlerken altyazısını ingilizce yapıyordum. Çok zorlanıyordum bunları yaparken ama bir süre ısrarla devam ettim ama sonra fark ettim ki YDS'deki okuma parçalarını ve çevirileri yapmak için başka tekniklere ve test bilgisine ihtiyaç var, bunlarla zaman harcamanın bir anlamı yok ve ben de bıraktım. (K8)" diye belirtmiş ve bu tür sınavların dil eğitiminde bireyleri çoktan seçmeli testlere yönelttiğini ve amaca odaklanmak adına sadece dil sorusu çözmeye ve ilgili tekniklere zaman ayırmaya sevk ettiğini dile getirmiştir.

Katılımcıların önemli bir kısmı (29 kişi) dil materyali ve başvuru kaynağı deyince akıllarına hemen dilbilgisi kitaplarının geldiğini ve bu tarz materyallerden YDS ve YÖKDiL'e hazırlanırken sıkça faydalandıklarını belirtmişlerdir. "Adını hatırlayamadı̆ım bir gramer kitabı vardı. Yazarı Türk olan. Oradaki kurallar bire bir KPDS, ÜDS, YDS işte neyse hepsinde çıkıyordu. Sanki soruları o adam hazırlıyormuş gibi. Cümle tamamlamalar, tense soruları hep onun elinden çıkmış gibi, belki o da komisyondaydı bilmiyorum orasını ... (K30)". Dilbilgisi kitaplarının sadece sınavlar için değil neredeyse tüm dil eğitimi süreci içinde en etkin kaynak olduğunu belirten başka bir katılımcı: "Bizim ortaokul ve lise Ingilizce derslerinden kullandığımız bir iki gramer kitabı vardı Anadolu Lisesinde ders için kullanılan ve ünite ünite oradaki konuları işlerdik ve ne olsa aklımıza gelen ilk başvuru yeri o gramer kitabıydı. (K1)" derken dilbilgisi öğretimi algısının materyal seçimine olan direkt etkisini de dile getirmiştir. Bu durum Türkiye'de yabancı dil eğitiminde dilbilgisi eğitimine verilen önemin de göstergesidir.

Katılımcıların YDS ve YÖKDiL sınavlarının dil eğitimi materyallerine etkileriyle ilgili görüşlerinde bir diğer alt tema görsel ve işitsel materyallerin hiç sürece dahil edilmemesi şeklinde ortaya çıkmıştır. Akademisyenlerden bir kısmı bu sorunu dolaylı yollardan ifade ederken bir kısmı (12 katılımcı) YDS ve YÖKDiL gibi çoktan seçmeli yabancı dil sınavlarına hazırlanırken dinleme ve izlemeye hiç başvurmadıklarını zira yabancı dili sadece okuyarak ve hedef yapıları ilgili bağlamlarda görüp tanıyarak, onlarla ilgili sorulara verilen soru şıklarına bakarak cevap verdiklerini belirtmişlerdir. "iletişim için değil, test çözmek için dil çalıştık ve şimdi de sıkıntısını çekiyoruz. Ingilizce bir şey duyduğunda, tekrar ettirmeden ve başkasından yardım istemeden direkt anlayıp gereğini yapan kaç hoca var acaba? (K35)" diyen katılımcı dinleme becerisi konusunda yaşanılan ortak sıkıntıyı dile getirirken "Bazen Youtube'da filan ingilizce bir şeyler izlediğim de hoppala bu ne diyorum, alt yazılı izlediğimde ise çok bir sıkıntı kalmıyor. Niye sizce, okumaya alışmışız 
görmeye duymaya değil. (K10)" diyen katılımcı da hem işitsel hem görsel açıdan dil eğitiminde eksiklik olduğunu, yabancı dilde okuma alışkanlığının etkin olduğunu ve bunun yüzünden görsel ve işitsel aktarımlarda sıkıntı yaşandığını dile getirmiştir.

\section{Akademisyenlerin YDS ve YÖKDiL sınavlarının dil eğitimi ortamlarına etkileriyle ilgili görüşleri}

Araştırma sorularından üçüncüsü YDS ve YÖKDiL sınavlarının yabancı dil eğitim ortamları üzerindeki etkilerini belirleme amacıyla sorulmuştur. Çalışmaya katılan akademisyenlerin bu soruya verdikleri yanıtlar (1) Dershane mantığı, (2) Türkçe kullanımı ve (3) Kural ve kelime eğitimi olmak üzere 3 alt tema etrafında gruplandırılmıştır. YDS ve YÖKDiL sınavlarının yabancı dil eğitim ortamları üzerindeki etkileri akademisyenlerce genellikle (32 katılımcı) olumsuz olarak tanımlanmıştır. Katılımcılara YDS ve YÖKDIL gibi çoktan seçmeli yabancı dil sınavlarının dil eğitimi ortamlarına nasıl etki ettiği sorulduğunda ortaya çıkan ilk alt tema olan "dershane mantığını" açıklamaları istendiğinde akademisyenlerin çoğu dil eğitiminin bu sınavların içeriği ve soru tipleri yüzünden herhangi bir dersin sınavına hazırlanıyormuşçasına yapıldığını bildirmişlerdir ( 23 kişi). Katılımcılardan bazıları ( 9 akademisyen) bu sınavlara hazırlanmak için örgün veya yaygın hiçbir eğitim almadıklarını, kendi başlarına çalışıp hazırlandıklarını belirtirken, diğerleri özel ders aldıklarını veya dershaneye gittiklerini ve bu esnada Türkiye'de yapılan tüm merkezi sınavlarda olduğu gibi amaç ve sonuç odaklı çalışmalar yaptıklarını belirtmişlerdir. "Herkes o dönem ne yapıyorsa ben de aynısını yaptım. Bir dershaneye gidip ders aldım, soru çözdüm ve ilkinde değil ikinci denemede istediğim puanı aldım. (K39)" diyen bu katılımcı dil eğitimini dershane tarzı olarak bilinen ve beceri odaklı değil amaç ve hedef odaklı eğitim şeklinde almayı tercih ettiğini ve sonuç olarak dil yeterliği anlamında istediğini aldığını ifade etmiştir. Bir başka katılımcı dil çalışırken odağının soruyu doğru cevaplamak olduğunu ve karşılaştığı metnin anlamı konusunda hiç kafa yormadığını dile getirmiştir: "Test çözerken benim için kelimenin anlamından çok, sonrasında hangi "prepozisyonu" aldığı filan önemliydi. Doğru şıkkı bulduysam tamamdı hiç uğraşmazdım, gerisi hiç kimsede hiç kalmadı ki zaten ... (K15)".

Yabancı dil ortamlarının nasıl etkilendiği sorusuna verilen cevaplardan ortaya çıkan alt temalardan biri de dil derslerinde Türkçe kullanımıydı (20 katılımcı). Test teknikleri ve kısa yolların daha kısa zamanda daha net anlaşılması için en etkili anlatım dilinin elbette ki anadil olacağını vurgulayan katılımcılar bu yüzden dil derslerinde tamamen Türkçe ders anlatıldığını ve bu durumun yeni yeni kendilerine garip ve anlamsız geldiğini iletmişlerdir. "Hep Türkçe ders yapılan ve sadece kelime anlamı şudur, kural böyledir gibi ders anlatılan bir yer düşünün. Orada dil öğrenmeniz mucize olurdu zaten bence. (K5)". Öte yandan şimdilerde özellikle özel okullarda benimsenen modern dil eğitim yöntemleriyle kendi dil eğitimini karşılaştıran bir katılımcı: "Kızımın ingilizcesi bence benden iyidir ve daha 11 yaşında. Dil derslerini çok seviyor ve sürekli interaktif bir şeyler yaparak, şarkılar söyleyerek dil öğreniyorlar ve derslerde Türkçe yasak. Düşünün şimdi bu çocuk tabi ki benden daha iyi dil öğrenecektir. (K24)" diyerek bu konuda ciddi bir değişimin başladığını, dil derslerinde Türkçe kullanımının terkedildiğini ve bunun olumlu yansımalarının görüldüğünü kendi dil eğitimiyle kıyas yaparak söylemiştir. Öte yandan dil derslerinde Türkçe kullanımı konusunda bir katılımcı: “ $O$ zamanlar hizmet içi yabancı dil dersleri alıyorduk ve hepimizin amacı sınavdan bir an evvel yeterli dil puanını alabilmekti. ilk zamanlar derse gelen hoca dersi tamamen ingilizce işliyordu ve bizi konuşturmaya çalışıyordu ve bu haliyle çok benimsenmedi çünkü bizim derdimiz başkaydı. Nihayetinde hocayla konuşup ikna ettik ve o da tamamen Türkçe ders işleyip sadece sınava yönelik ders anlatmaya başlamıştı. Ha iyi mi etmiştik hayır ama sınavı öyle geçtik işte. (K20)" diyerek aslında yabancı dil öğrenirken anadil kullanılmaması konusunda kendi fikrini de açıklamış ancak Türkiye'deki dil sınavlarının hedef ve içerikleri göz önünde bulundurulduğunda sınava ilişkin dil eğitiminde Türkçe kullanımının gerektiğini ifade etmiştir.

Akademisyenlere YDS ve YÖKDiL gibi çoktan seçmeli yabancı dil sınavlarının dil eğitimi ortamlarına nasıl etki ettiği sorulduğunda ortaya çıkan bir başka alt tema yabancı dil derslerinde fazlaca kural ve kelime eğitimi yapıldığı şeklinde ortaya çıkmıştır (16 katılımcı). Dil eğitiminin tamamen dilbilgisi kuralları ve bilinmeyen kelimelerin öğretimi gibi algılandığı ve bu durumun hem sıkıcı hem de verimsiz dersler olarak kendilerine geri döndüğünü belirtmişlerdir. "Sadece dil sınavları için değil daha önceki ingilizce derslerinde de durum benzerdi. "Tense"leri öğretirler ve bazı okuma parçalarında geçen kelimeleri görürdük tamam, inanılmaz sıkıcı ve monotondu. Kimse doğru dürüst kendini bile tanıtacak kadar dil bilmezken hepimiz iyi notlarla sınıfları geçtik. (K43)". Kelime öğretilmesi konusundaysa bir katılımcı yüzlerce kelimeyi ezberleyerek öğrendiğini, bugün bile bazılarını hatırladığını ancak kullanamadığı için bütün bunların sınavı geçmek dışında bir işe yaramadığını dile getirmiştir: "Akademik kelime listesi vermişti hoca ve 1500-2000 civarında kelimeyi ezberlemiştim. Gerçekten. Şimdi bile bazıları aklımda ama hiç kullandın mı diye sorun, hayır. Gerisini getiremem ki çünkü biliyorum. (K35)".

\section{Akademisyenlerin YDS ve YÖKDiL sınavlarının dil öğrenimi çıktılarına etkilerine ilişkin görüşleri}

Araştırmada cevap aranan sorulardan dördüncü ve sonuncusu YDS ve YÖKDiL sınavlarının Türkiye'deki yabancı dil öğrenimi çıktılarına etkilerinin tespit edilmesi hususundadır. Konuyla ilgili akademisyen görüşleri incelendiğinde eldeki yanıtlar (1) Okuma ve çeviri becerileri ve (2) Yazma ve konuşma becerileri olmak üzere 2 alt tema etrafında gruplandırılmıştır. YDS ve YÖKDí sınavlarının yabancı dil öğretimi çıktıları üzerindeki etkileri akademisyenlerce genellikle (27 katılımcı) olumsuz olarak tanımlanmıştır. Öte taraftan katılımcıların bir kısmı (16 kişi) araştırma sorusuyla ilgili ilk alt tema olan çeviri yapma ve hedef dilde 
okuma becerilerine YDS ve YÖKDIL sınavlarının pozitif katkısı olduğu yönünde görüş bildirmişlerdir. Konuya ilişkin görüş bildiren bir katılımcı: "Öğrenim çıktıları derken sizin aslında ne amaçladığınız mı başkalarının sizin adınıza ne amaçladığı mı sorusu akla geliyor. Evet ben İngilizce konuşamıyorum ve yazma konusunda da önemli sorunlar var ancak çeviri konusunda ve okuma becerisinde gayet başarılı olduğumu hissediyorum ki bu sınavların belki gerçek amacı da budur. (K25)" diyerek sınavların amacı konusunda ki katılımcıların gözündeki belirsizliği dile getirmiştir. Çeviri yapabilme konusunda bir diğer katılımcı: "KPDS ve benzeri sınavlar il çıktıkları yıllarda Türkiye'de kamu kuruluşlarında yabancı dil ihtiyacını karşılayacak kadar İngilizce bilen elemanların tespiti için kullanıldı. Bunlar sonradan amaçlarının dışında da kullanılmış olabilir ama bu gibi sınavların öncelikli amacı zaten çeviri yapabilen, okuduğunu anlayabilen ve gerektiğinde bunu sözlü veya yazılı dile getirebilenleri tespit etmekti ve bence bu anlamda bu sınavlar amaçlarına hizmet ediyorlar. (K6)" derken aslında eğer amaçlanan adayların çeviri yapabilme ve okuduğunu anlama gibi dil becerilerini ölçmekse sınavların işlevlerini yerine getirdiğini ifade etmiştir.

Buna karşın katılımcıların genelde (27 katılımcı) YDS ve YÖKDiL sınavlarının yabancı dil öğrenimi çıktılarına olumsuz etkide bulunduğunu bildirdikleri görülmüştür. Bu konuda görüş bildiren bir akademisyen: "Düşünüyorum da bizlerden TOEFL vs. gibi sınavlardan puan almamız istenseydi biz mecburen İngilizce yazmaya ve konuşmaya ağırlık verecektik. Ha bu çok daha zor olacaktı, kesinlikle ama hiç olmazsa dil öğrenmiş olurduk. (K41)" derken YDS ve YÖKDiL sınavlarında yabancı dilde konuşma ve yazma becerilerinin ölçülmemesinin kendi dil öğrenim çıktılarına olan olumsuz etkisini dile getirmiştir. Son olarak bugün Profesör kadrosunda olan ve yıllardır her aşamada ders verdiğini belirten bir başka katılımcı da: "Ta 25-30 sene evvel girdim dil sınavına ve oradan aldığım puan üzerinden yabancı dili biliyor varsayıldım. Geçen onca zaman içerisinde kimse sormadı sen gerçekten İngilizce ne yapabiliyor neyi yapamıyorsun diye. Bence bu kısmında eksiklik var, ben belki hiç tek kelime konuşamıyorum. Kim bilecek? (K4)" çoktan seçmeli dil sınavlarının iletişimsel becerileri ölçmede ne denli yetersiz kaldığının bir kez daha altını çizerken katılımcıların bu söylemleri akademisyenlerin yabancı dil seviyelerinin Türkiye'de zaman içerisinde hiç ölçülmediği gerçeğine de dikkat çekmiştir.

\section{SONUÇ}

2018-2019 yılları arasında yapılan bu çalışmada Eskişehir ilinde yer alan Anadolu Üniversitesi, Osmangazi Üniversitesi ve Eskişehir Teknik Üniversitesi'nden gönüllü olarak katılan toplam 43 akademisyenin YDS ve YÖKDíL sınavlarının yabancı dil eğitimi üzerindeki pedagojik etkileri konusunda görüşleri alınmış ve elde edilen bulgular ışığında araştırmaya konu edilen sınavların yabancı dil eğitimi yöntemlerine, dil eğitimi materyallerine, dil eğitimi ortamlarına ve dil öğrenimi çıtılarına olası etkilerine ilişkin saptamalar yapılmıştır. Illk olarak YDS ve YÖKDIL sınavlarının yabancı dil eğitim yöntemleri üzerindeki etkilerini masaya yatıracak olursak çalışmaya katılan akademisyenlerin görüşlerinin bu sınavların farklı yabancı dil becerileri konusunda olumlu ve olumsuz bir takım pedagojik etkilerini açığa çıkardığını görürüz. Bu etkilerin neler olduğu katılımcıların yabancı dil eğitim algısıyla ve günümüzde yabancı dil bilmek neyi ifade eder ve bir yabancı dil bilen neler yapabilmelidir konusundaki fikirleriyle yakından ilgilidir. Öyle ki klasik dil eğitim yöntemlerinde ağırlıkla üzerinde durulan öğrencilere dilbilgisi kurallarını öğretme, kelime ezberletme ve çeviri yaptırma gibi yabancı dil aktivitelerinin yararına inanan ve bunları dil bilme adına önemli sayan katılımcıların YDS ve YÖKDíL sınavlarının yabancı dil eğitim yöntemleri üzerinde olumlu etkisi olduğuna inandıkları ve kendi deneyimleriyle bunu örneklendirdikleri görülmüştür. Öte taraftan katılımcıların önemli bir kısmı (35 katılımcı) YDS ve YÖKDiL sınavlarının soru tipleri, içerikleri ve ölçtüğü beceriler yüzünden kendilerini istemeden kelime ezberi yapmaya, çeviri yapmaya ve zor akademik okuma parçalarını okuyup anlamaya ittiğini ve bu durumun dil öğrenme algılarını olumsuz etkilediğini dile getirmişlerdir. Türkiye'de yapılan çoktan seçmeli yabancı dil sınavlarının farklı yabancı dil becerileri göz önünde bulundurulduğunda değişik etkileri olduğu Akpınar ve Çakıldere'nin (2013) çalışmasında da ortaya çıkmış ve bu tarz sınavların adayların okuma becerileri üzerinde olumlu etkileri olabileceği belirtilirken iletişim kurmayla ilgili beceriler konusunda olumsuz etkilerinin olabileceğinin altı çizilmiştir. Nitekim bu çalışmada da benzer sonuçlara ulaşılmış, akademisyenler YDS ve YÖKDiL gibi çoktan seçmeli yabancı dil sınavlarından yeterli puanlar almalarına rağmen İngilizce yazma ve konuşma konusunda ciddi sıkıntılar yaşadıklarını ve belki bu sınavların içerikleri sadece doğru dilbilgisi yapılarını, kelime kullanımlarını ve çeviri karşılıklarını ölçmeye odaklanmasaydı başka dil becerilerini geliştirme konusunda istek duymuş olabileceklerini belirtmişlerdir.

Şüphe yok ki yabancı dil derslerinde kelime ve dil dilbilgisi yapılarının öğretimi ve bunların sınavlarda ölçülmesi zararlı ve olmaması gereken yabancı dil eğitim süreçleri değildir, bu noktada önemli olan kelime ve dilbilgisi eğitimin anlamlı hale dönüştürülebilmesi yani üretim seviyesine çıkarılabilmesidir. Yabancı dil öğrenenler farklı zaman kalıplarını, bağlaçları, farklı sıfat ve filleri öğrenirlerken amaç bunları gördüklerinde tanımaktan veya bir testte gerekli boşluğa gelecek şekilde seçilmesinden ziyade bu yapı ve kelimeleri kullanarak yabancı dillerini zenginleştirmek ve ilerletmek olmalıdır. Katılımcıların birçoğu bu sınavlarda yıllardır ısrarla önemle üzerinde durulan karmaşık dilbilgisi yapılarının ve akademik kelime çeşidinin şu an ki yabancı dil ihtiyaçlarını karşılama konusunda fazla işe yaramadığını, dil öğrenenleri kendilerince test taktikleri, sınav stratejileri geliştirmek gibi oldukça lüzumsuz ve konu dışı beceriler geliştirmeye ittiğini ve bütün bunlarla uğraşmanın kendilerine dil becerisi kazandırmak bir yana, zaman ve enerji kaybettirdiğini dile getirmişlerdir. Gür (2012) çalışmasında bu sorunun altını çizmiş ve Türkiye'deki merkezi yabancı dil sınavlarının gerçekte neyi ölçtüğü konusunda şüpheler olduğunu, yabancı dil öğrenimi ve öğretiminin de gerek amaçlarının gerekse yöntemlerinin bu sınavlardan olumsuz etkilendiğini dile getirmiştir. 
Çalışmada görüş bildiren akademisyenlerin özellikle üzerinde durduğu hususlardan bir diğeri de YDS ve YÖKDíL sınavlarının içerik ve soru tipi bakımından gündelik hayatın gerektirdiği yabancı dil becerilerinin gerisinde kaldığını, görsel ve işitsel anlamda hiçbir öge barındırmadıklarından adayların bu sınavlara hazırlanırken kullandıkları materyal çeşitliliğini de olumsuz anlamda etkilediklerini belirtmişlerdir. Katılımcıların birçoğu sınavlardan başarılı oldukları halde İngilizce bir videoyu anlamakta sıkıntı yaşadıklarını, İngilizce bir mesajlaşma anında ne yapacaklarını bilemediklerini yani bir başka deyişle gerek aldıkları yabancı dil eğitimin içeriğinden ötürü gerekse YDS ve YÖKDiL sınavlarının içerdiği ve içermediği dil becerilerinin yüzünden vaktiyle yeterince iletişimsel dil öğrenimine ağırlık vermediklerini ve günümüzde gerekli olan dil ihtiyaçlarını gereğince karşılayamadıklarını dile getirmişlerdir. McEven (1995) bir dil sınavında test edilen becerinin önem verilen bir beceri olması gerektiğini çünkü eğitimi verilen ve üzerinde durulan becerinin sınavlarda ölçüldüğünü ve bu durumun öğrenciler için hep böyle algılandığını belirtmiştir. Eğer dil sınavlarında konuşma, yazma ve dinleme gibi becerileri ölçülmezse gerek bu konuda eğitim verenlerin gerek adayların halihazırda ölçülen dil becerilerine yönelmeleri, kullandıkları materyalleri ve benimsedikleri dil öğrenme yöntemlerini de o sınavın içeriğine göre seçmeleri kaçınılmaz olur ve ne yazık ki çalışmaya katılan akademisyenlerin dile getirdikleri yabancı dil sıkıntılarının nedenlerinden biri de budur.

Katılımcılarca dile getirilen bir başka bulgu da bu sınavlar yüzünden yabancı dil öğrenmenin herhangi bir derse çalışmak gibi algılandığı, çoktan seçmeli soru tipi yüzünden dil öğrenmek yerine doğru dil yapısını öğrenmenin ve onu tanımanın öne çıktığı ve bu yüzden akademisyenlerin yabancı dillerini geliştirme konusunda hiç yol alamadıkları konusundadır. Bu nedenle dil derslerinde özellikle dilbilgisi kitaplarına ve kelime bilgisine ağırlık verildiğini belirten katılımcıların çoğunluğu sınavlara hazırlanırken bu kadar kural ve kelime öğrenmelerine rağmen konuşma ve yazma konusunda büyük sıkıntı yaşadıklarını dile getirmişlerdir. Külekçi (2016) YDS'nin sınav etkileri konusunda yaptığı çalışmasında aynı soruna değinmiş, sınav içeriğinin dilbilgisi yapılarını öne çıkarması ve pratik dil becerilerinin ölçülmesi konusundaki eksikliği yüzünden adayların yabancı dilde konuşma ve yazmaya hiç zaman ayırmadıklarını ve bu durumun YÖKDiL ve YDS'nin olumsuz etkisi olarak adaylar tarafından dile getirildiğini belirtmiştir. Bu bulgular aynı zamanda Türkiye'de ortaokul ve liselerdeki yabancı dil derslerinde genel olarak görülen dilbilgisi eğitimi, kelime öğreti-mi ve hedef dilde okuma gibi yaygın dil aktivitelerinin neden bu kadar kanıksandığı konusunda da fikir verebilir. Kopriva'nın (2008) ölçmenin önemine değindiği kitabında sorduğu gibi, bir hoca için en kolay soru hazırlanacak ve en pratik yoldan ölçme ve değerlendirmesi yapılacak dil becerileri sizce hangisi veya hangileridir: konuşma, yazma, dinleme, okuma, dilbilgisi kullanımı veya kelime bilgisi?

Ölçmede sıkıntı yaratacak ve ölçmeye boyut kazandıracak değişkenler göz önünde bulundurulduğunda en kolay olanları dilbilgisi kullanımı ve kelime bilgisi olarak gösterilebilir zira hem sınav hazırlaması hem de değerlendirmesi diğer becerilere kıyasla daha kolay olacaktır ve belki de Türkiye'de yabancı dil derslerinde yaygın olarak görülen konuşma, dinleme ve yazma eğitiminden ziyade dilbilgisi ve kelime öğretimi alışkanlığının açıklayıcı gerekçelerinden biri de belki de dilbilgisi ve kelime öğretimindeki bu sistematik, ölçümünde ve değerlendirilmesindeki kolaylıktır ve ne yazık ki bu durum ülke genelinde yapılan sınavlarda dahi kendisini göstermekte adayların konuşma ve yazma becerileri ölçülmemektedir. Brown (1998) daha geçerli dil sınavları yapmak için adayların konuşma ve yazma becerilerini ölçmek gerektiğini belirtmiştir ve bunun için de ya hedef dili konuşma ve yazılı anlatım sınavlarında ölçme üzerine eğitim almış, konuyla ilgili deneyim ve tecrübeye sahip ve verdiği notların güvenirliği kanıtlanmış değerlendiricilerden oluşan jürilere ya da içerisinde yapay zekâ uygulaması barındıran dil ölçme üzerine tasarlanmış bilgisayar programlarına ihtiyaç vardır. Bu seçeneklerin her ikisi de oldukça fazla maddi külfet, zaman ve geçerlik ve güvenirlik sorunlarını da beraberlerinde getirdiklerinden bu gibi uygulamalara her eğitim kurumu sıcak bakmaz. Ancak şu da bir gerçektir ki yordamlayıcılığı kanıtlanmadan hiçbir dilbilgisi, kelime bilgisi veya çeviri sınavının sonucu adayın genel dil yeterliği olarak düşünülmemeli ve kullanılmamalıdır (Alderson,1992). O halde dil sınavlarının geçerliği mi kullanışılığı mı yoksa her ikisi de mi gibi bir soruya eldeki imkanlar, ülkenin eğitim ihtiyaçları ve dil yeterliği anlamında yaşanan sorunlar göz önünde bulundurularak bir cevap bulunmalıdır. Çoktan seçmeli soru tipinin kullanıldığı okuma, dinleme, kelime ve dilbilgisi ölçme amaçlı sınavların yanı sıra adayların hedef dilde farklı bağlamlarda konuşma ve yazma becerilerinin de ölçüldüğü (TOEFL, IELTS, PTS gibi) dil sınavları hem uluslararası eğitim çevrelerince iyi bir dil sınavının ihtiva etmesi gereken içerik ve hedefleri anlamında kabul görebileceği hem de gerek dil eğitimcilerinin gerekse öğrencilerin yabancı dil eğitimi ve sınavları nasıl olmalı, neleri içermeli konusundaki kaygılarını giderebileceği üzerinde durulması gereken bulgular olarak karşımıza çıkmaktadır.

Bu çalışmadan elde dilen bir diğer sonuç ise yabancı dil öğrenim çıktılarının günümüzde Türkiye'de neler olduğu, neler olması istendiği konusundaki çeşitlilik ve bu konuda akademisyenlerin görüşlerinin ne denli farklılaştığıdır. Türkiye ne yazık ki yabancı dil yeterliği konusunda Avrupa ülkeleri arasında son sıralarda yer almakta ve özellikle içerisinde yazma ve konuşma yetilerinin ölçüldüğü uluslararası sınavlarda oldukça başarısız sonuçlar almaktadır (Polat, 2018). Aslında konuyla ilgili en önemli otorite olan Millî Eğitim Bakanlığı yabancı dil yeterliği konusunda beklentileri çok net açıklamıştır. Millî Eğitim Bakanlığı Yabancı Dil Eğitimi ve Öğretimi Yönetmeliği'nde (Resmî Gazete, 31.05.2006/26184) Türkiye'deki yabancı dil eğitiminin amaçları listelenerek dil öğrenenlerden aslında hangi becerilerin beklendiği şu şekilde ifade edilmiştir:

"Madde 5- (1) Örgün, yaygın ve uzaktan öğretim kurumlarındaki yabancı dil eğitimi ve öğretiminin amacı, Millî Eğitimin genel amaç ve temel ilkelerine uygun olarak okul ve kurumların amaç ve seviyeleri de göz önünde bulundurularak eğitim ve öğretimi yapılan yabancı dilde bireylerin; Dinleme-anlama, okuma-anlama, konuşma ve yazma becerilerini kazanmalarını, 
öğrendiği dilde iletişim kurmalarını ve yabancı dil öğretimine karşı olumlu tutum geliştirmelerini sağlamaktır (MEB Tebliğler Dergisi, Mayıs 2006- Ek 2585)."

Yabancı dil bilen bireylerin o dilde yazmaları, konuşmaları, dinlediklerini ve okuduklarını anlamalarının beklendiği açıktır ve bu becerilerin ölçümü ancak buna uygun sınavlar marifetiyle olabilir. Halbuki YÖKDíL ve YDS sınavlarının içerikleri konuşma, dinleme ve yazma becerilerinin ölçümü konusunda yetersizdir. Gür (2012) çalışmasında bu sınavların içeriklerinin temelde aşağıda verilen soru içeriklerinden oluştuğunu belirtmiş ve yabancı dilde iletişim becerilerinin ölçümünde kullanılamayacaklarını ifade etmiştir. YDS ve YÖKDIL'in içeriği:

- Dilbilgisi ölçümü, kelime yerleştirme ve cümle tamamlama,

- Karşılıklı iki dilden çeviri yapabilme,

- Diyalog tamamlama ve duruma uygun ifadeyi bulma,

- Eşanlama gelen ifadeyi bulma

- Okuma becerileri ve anlam bütünlüğünü bozan ifadeyi bulma sorularından oluşmaktadır.

Anlaşılacağı üzere Türkiye'deki merkezi yabancı dil sınavları adayları okuma, çeviri, kelime ve dilbilgisi anlamında sınamakta, bunların dışında yazma, konuşma ve dinleme becerileri anlamında soru içermemektedir. Konuyla ilgili olarak bu çalışmada bazı akademisyenlerin okuma ve çeviri gibi becerileri yabancı dil bilmek olarak düşündükleri ve yeterli gördükleri sonucu ortaya çıkmıştır ve belki de YDS ve YÖKDiL sınavlarıyla ulaşılmak istenen ölçme hedefinin bu olduğu varsayımı dile getirilmiştir ancak özellikle uluslararası toplantı, kongre, öğretim elemanı değişim programlarına katılan ve yabancı dili iletişim ihtiyaçları için gerekli gören akademisyenlerin bu fikre katılmadıkları görülmüştür. Akademisyenlerden bazılarının YDS ve YÖKDiL'de yabancı dilde konuşma, yazma ve dinleme gibi becerilerin ölçülmesi halinde (ki bu durumda dil öğrenen ve sınavlara giren herkesin bir dönem zorlanacağı ve bunun öngörülebilecek ve göğüslenebilecek bir durum olacağı söylenmiştir) bireylerin kendilerini buna adapte edeceklerini ve bu şekilde hedef dilde yeterince iletişim kuracak yetiye sahip olabileceklerini dile getirmişlerdir.

Söz konusu sınavlarda hedef dilde üretim adına hiçbir bölüm olmamasının adaylara yabancı dil öğrenim yöntemleri konusunda aslında hiç istenmeyen mesajlar verdiği ve boşluk doldurma veya doğru karşılığı bulma gibi daha alt bilişsel becerilerin ölçülmesi yoluyla yabancı dilin sınanabileceği gibi aslında hiç de doğru olamayan çıkarımlara götürebileceği belirtilmiştir. Burada aslında soru tipi ve çeşidinden öte yabancı dil yeterliği kapsamında hangi dil becerilerinin ne ağırlıkta ölçülmesi gerektiği konusu ön plana çıkarılmalıdır. Brown (1998) yabancı dil seviye tespit ve yeterlik sınavlarında dinleme, konuşma ve yazma becerilerinin yüksek maliyet, iş gücü ve zaman gerektirmesine karşın yapılmasının önemine değinmiş ve ancak bu beceriler yeterince ölçüldüğü taktirde sınavın geçerliliğinden söz edilebileceğini savunmuştur. Çalışmaya katılan akademisyenlerce yabancı dil yeterliğinin ancak o dil kullanılarak sözlü, yazılı ve işitsel iletişim becerilerinin sergilendiği bir sınav sistemi yoluyla tam olarak ölçülebileceği ve bu konuda YDS ve YÖKDiL gibi çoktan seçmeli yabancı dil sınavlarının adayların yabancı dil öğrenirken otoritelerce benimsenmiş hedef becerileri edinme ve becerileri içselleştirme adına olumsuz etkileri olduğu dile getirilmiştir. Benzer bir sonuç Yeşilyurt (2016) tarafından da dile getirilmiş ve çoktan seçmeli yabancı dil testlerinin Türkiye'deki akademisyenlerin yabancı dillerini geliştirme anlamında profesyonel ve kişisel gelişimleri üzerinde olumsuz etkileri olduğunu, bu tarz sınavların dil öğrenen bireylerin yabancı dil algılarını negatif yönde etkilediğini ve pedagojik anlamda istenmeyen sonuçlar doğurduğunu dile getirmiştir. İyi bir yabancı dil eğitiminin kelime ve dilbilgisi eğitiminin yanı sıra sesletim bilgisi de verilerek, farklı bağlamlarda ve farklı aksanlarla konuşan bireylerin söylediklerinin anlaşılması için yeterince dinleme yaptırılarak ve günümüz sosyal medya ve elektronik posta kullanımının yaygınlığı göz önünde bulundurularak farklı amaçlar ve formatlara uygun yazma becerilerinin de kazandırılması yoluyla gerçekleştirilebileceği belirtilmiştir.

\section{ÖNERILER}

Araştırmadan elde edilen sonuçlar ışığında birtakım önerilerde de bulunulabilir. İlk olarak Türkiye'de sırf uygulaması hızlı, ekonomik ve güvenli diye neredeyse hiçbir gelişmiş ülkenin kullanmadığı ve sonuçlarına güvenmediği çoktan seçmeli dilbilgisi, çeviri ve kelime sorularından müteşekkil dil sınavlarının kullanımı tekrar gözden geçirilip konuyla ilgili araştırma sonuçlarını da dikkate alarak yabancı dil yeterliğinin sınanmasında yeni bir ölçme değerlendirme politikası geliştirilmeli ve bu politikaya uygun içerisinde hedef dilde üretime ağırlık veren soru çeşidinin ve yönteminin olduğu, günümüz web tabanlı bilgisayar destekli ölçme tekniklerinden faydalanan ve gerçek anlamda dünyadaki eşdeğerleriyle benzer becerileri ölçen dil sınavları geliştirmek konusunda harekete geçilmelidir.

Bir taraftan sınavlarda yabancı dilde konuşma, dinleme ve yazma gibi becerilerin beklendiğini söyleyip diğer taraftan neredeyse ülke çapında tüm dil derslerinde hala klasik dilbilgisi eğitimi verme, çeviri yaptırma, kelime ezberi isteme gibi modası çoktan geçmiş 
dil aktivitelerinin üzerinde durulmasına da seyirci kalınamaz. Araştırmada da ortaya çıktığı üzere YDS ve YÖKDíL sınavlarının soru tipleri ve ölçmedikleri becerilerin eksikliği nedeniyle katılımcıların altını çizdiği olumsuz etkiler kendilerini yabancı dilde konuşamamak, yazamamak ve dinlediğini anlayamamak şeklinde göstermiştir. $\mathrm{O}$ halde bu olumsuz etkileri bertaraf edebilmek için sadece sınavları değiştirmek yeterli olmayacaktır. Dil eğitimcilerinin yabancı dil eğitimi hedeflerini gözden geçirmeleri ve günümüz iletişim olanaklarını dikkate alarak yeni dil eğitim yöntemleri benimsemeleri teşvik edilmeli ve bu konuda tüm paydaşlar (okul yönetimleri, veliler, öğrenciler ve tabi ki öğretmenler) bilgilendirilmelidir.

Son olarak merkezi sınavların avantajlı tarafları olduğu gibi dezavantajlı taraflarının da olduğu gerçeği kabul edilmeli ve sınav etkisi konusunda yapılan bilimsel çalışmaların sonuçları değerlendirilmelidir. Türkiye'de ölçme ve değerlendirme konusunda ulusal eğitim amaçları ve hedeflenen amaçlara ne ölçüde ulaşılabildiği hususu gerçekçi bir şekilde tartışmaya açılmalı ve özellikle yabancı dil eğitimi alanında yaşanan sıkıntıların üzerine gitmek adına kolay ve alışılagelmiş yöntemlerden vaz geçerek yeni ve etkili dil öğretim metotları, yabancı dil materyalleri, dil sınıflarının oluşturulması ve öğrenim çıktıları belirlenip hazırlanması için harekete geçilmelidir. Ölçme değerlendirme boyutu bu değişimin sadece bir ayağını oluşturacaktır ancak çalışma sonuçlarının da ortaya koyduğu üzere sınavların yabancı dil eğitimi üzerine etkileri oldukça anlamlı ve düşündürücüdür.

\section{Etik Kurul Onay Bilgileri}

Çalışma 2020 yılından önce yapıldığı için Etik Kurul raporu alınmasına gerek olmamıştır.

\section{KAYNAKÇA}

Akın, G. (2016). Evaluation of national foreign language test in Turkey. Asian Journal of Educational Research, 4(3), 11-21. Edinilme tarihi Kasım, 2019. http://www.multidisciplinaryjournals.com/wp-content/uploads/2016/04/FULLPAPER

Akpınar. K.D., \& Çakıldere. B. (2013). Washback effects of high-stakes language tests of Turkey (KPDS and ÜDS) on productive and receptive skills of academic personnel. Journal of Language and Linguistic Studies. 9(2). 81-94. ISSN: 1305- 578X

Alderson, J.C. (1992). Guidelines for the evaluation of language education. (274-304). Cambridge University Press.

Alderson, J.C., \& Wall, D. (1986). Does washback exist? Applied linguistics. 14, 115-129.

Altunışık, R., Çoşkun, R., Yıldııım, E., \& Bayraktaroğlu, S. (2010). Sosyal Bilimlerde Araştırma Yöntemleri. 6.Baskı, Sakarya: Sakarya Kitabevi.

Aydın, B., Akay, E., Polat, M., \& Geridönmez, S. (2016). Türkiye'deki Hazırlık Okullarının Yeterlik Sınavı Uygulamaları ve Bilgisayarlı Dil Ölçme Fikrine Yaklaşımları. Anadolu Üniversitesi Sosyal Bilimler Dergisi. 16 (2), 1-19.

Aypay, A., Cemaloğlu, N., Sarpkaya, R., Tomul, E., Baştürk, R., Ellez, M., Şahin, B., Yolcu, H., Karakaya, İ., \& Turgut, Y. (2014). Bilimsel araştırma yöntemleri (Edt. Abdullah Tanrıöğen) (4.Baskı). Ankara: Anı Yayıncılık.

Aziz, A. (1994). Araştırma yöntemleri teknikleri ve iletişim. (2. Baskı) Ankara: Turhan Kitabevi.

Bachman, L.F., \& Palmer, A. S. (1996). Language Testing in Practice. Oxford: Oxford University Press.

British Council Report. (2015). Türkiye'de Yükseköğretim Kurumlarındaki ingilizce Eğitimi. (RaporNo:2016021). British Council'dan Haziran, 2016'da edinilmiştir. https://www.britishcouncil.org/education/schools/support-for-languages/research-report

Brown. J. D. (1998). Testing in Language Programs. Upper Saddle River. NJ: Prentice Hall Regents.

Cheng. L. (2005). Changing language teaching through language testing: A washbackstudy. Studies in language testing. 21. Cambridge: Cambridge University Press.

Ching, P. Y. (2009). A review of washback and its pedagogical implications. VNU Journal of Science, Foreign languages. 25, 257-263.

Çelik, O., \& Yavuz, F. (2015). The relationship between speaking grades and listening grades of university level preparatory students. Procedia Social and Behavioral Sciences. 197 (2015) 2137 - 2140.

Fulcher, G., \& Davidson, F. (2007). Language testing and assessment: An advance resource book. New York, NY: Routledge.

Green, A. (2007). IELTS washback in context: Preparation for academic writing in higher education. Edinilme tarihi Nisan, 2019. http://hosted.jalt.org/test/PDF/Dunkley2.pdf

Gür. Ö. (2012). Ölçme Değerlendirme ve Kamu Personeli Dil Sınavı (KPDS) Bu Sınav Neyi Ölçüyor. Sakarya Üniversitesi Eğitim Dergisi. Sayı:2/1. ISSN: 2146-7455

Hatipoğlu, Ç. (2016). The impact of the university entrance exam on EFL education in Turkey: Pre-service English language teachers' perspective. Procedia-Social and Behavioral Sciences. 2/2, 136-144.

Hawkey, R. (2006). A study of the impact of IELTS, especially on candidates and teachers. British Council: 'Going Global', Edinburgh, Scotland. http://www.britishcouncil.org/goingglobal-session-2-1225-thursday-elt-roger-hawkey-paper.pdf

Heaton. J.B. (1988). Writing English Language Tests. Longman Handbook for Language Teachers. Longman.

Karaman. F. (2015). Yabancı Dil Sınavının Almanca Ölçme Aracı Olarak Değerlendirilmesi. Route Educational and social Science Journal. 2(1). Ocak 2015.

Kopriva, R. J. (2008). Improving testing for English language learners. New York, NY: Routledge.

Koru. S., \& Akesson. J. (2011). Turkey's English Deficit. Economy Policy Research foundation of Turkey. (RaporNo:201157). http://www.tepav.org.tr/upload/files/13244582121.Turkey s English Deficit.pdf 
Külekçi, E. 2016. A concise analysis of the Foreign Language Examination (YDS) in Turkey and its possible washback effects. International Online Journal of Education and Teaching. 3(4), 303-315. Edinilme tarihi Mart, 2019. http://iojet.org/index.php/IOJET/article/view/141/143

McEwen, N. (1995). Introducing accountability in education in Canada. Canadian Journal of Education. 20, 1-17.

MEB. (2010). Öğrenci Merkezli Eğitim Uygulama Modeli. MEB Tebliğler Dergisi. MEB sayfasından Mart, 2019’ da edinilmiştir.

http://yegitek.meb.gov.tr/earged/arasayfa.php?g=70

Messick. S. (1996). Validity and Washback in Language Testing. Educatonal Testing Service (ETS). Princeton. US.

Mirici, I.H. (2003). The factors affecting the success in English proficiency exams and possible contributions of the internet. Turkish Online Journal of Distance Education. 4(1): 1-8.

Oruç, N. E. (2015). Testing your Tests: Reliability Issues of Academic English Exams. International Journal of Psychology and Educational Studies. 2015, 2 (2), 47-52.

Özmen, K.S. (2011). Washback Effects of Inter University Foreign Language Examination on Foreign Language Competences of Candidate Academics. Novitas Royal (Research on Youth and Language). 5(2). 215-228.

Polat, M. (2018). Akademisyenlerin Yabancı Dil Bilgisi Seviye Tespit Sınavı'nın (YDS) Geçerliğiyle ilgili Tutumlarının Belirlenmesi. Anadolu Üniversitesi Sosyal Bilimler Dergisi. 18,4. Edinilme tarihi Ekim, 2019: https://dergipark.org.tr/download/article-file/693327

Poonpon, K. (2010). Expanding a second language speaking rating scale for instructional and assessment purposes. English Language Institute. 8, 69-94.

Rahimi, Z., \& Nazhand, N. (2010). The washback effect of IELTS preparation courses to the learners: Iranian learners' perspectives on IELTS preparation courses. doi: 10.1109/IC4E.2010.133

Rashidi, N., \& Javanmardi, F. (2011). The IELTS preparation washback on learning and teaching outcomes. Cross-Cultural Communication, 7(3), 132-144. doi: 10.3968/j.ccc.1923670020110703.162

Shepard. L. A. (1997). The centrality of test use and consequences for test validity. Educational Measurement: Issues and Practice. 16(2). 5-13.

Stobart, G. (2013). The impact of assessment: Intended and unintended consequences. Assessment in Education. 16, 139-140.

Sukyadi, D., \& Mardiani, R. (2011). The washback effect of the English national examination (ENE) on English teachers' classroom teaching and students' learning. 13(1), 96-111. doi: 10.9744/kata.13.1.96-111

Yavuzer. H., \& Göver. i. H. (2012). Akademik Personelin Yabancı Dil Durumu ve Yabancı Dil Sınavlarına bakışı: Nevşehir Örneği. Nevşehir Üniversitesi Sosyal Bilimler Enstitüsü Dergisi. 7-1,136-158.

Yesilyurt, S. (2016). An attempt for the exploration of academicians' experiences of the standard foreign language tests held in Turkey through metaphors. International Journal of Higher Education. 5(2), 263-274.

Yıldırım A., \& Şimsek H. (2011). Sosyal bilimlerde nitel araştırma yöntemleri (8. Baskı). Ankara: Seçkin. 